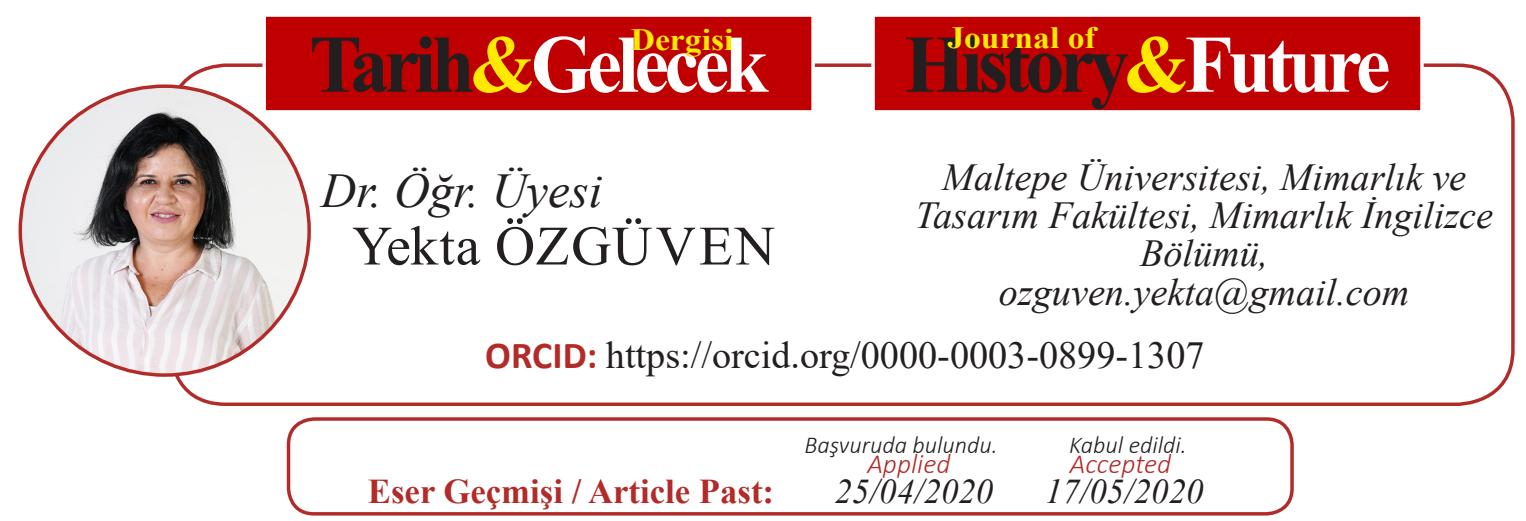

Araștırma Makalesi

DOI: http://dx.doi.org/10.21551/jhf.726854

Research Paper

Orjinal Makale / Orginal Paper

\title{
Mimarlık Süreli Yayınlarının Tarihsel Bağlamına Dair Bir Değerlendirme: Türkiye'nin İlk Mimarlık Dergileri ve Arkitekt
}

A Review on Historical Context of Architectural Periodicals: Pioneer Periodicals in Turkey and Arkitekt

$\ddot{O} z$

Illk süreli yayınlar, 17. yüzyılın ikinci yarısında Ingiltere'de ortaya çıkmakla birlikte; mimarlık ortamının süreli yayınlar ile karşılaşması daha geç bir tarihte gerçekleşmiştir. Bu süreli yayınların mimarlık alanındaki öncülleri ise, endüstrileşme pratiklerinin mimari üretim etkinliğini radikal biçimde değiștirmeye başladiğı İngiltere, Almanya ve Fransa gibi erken sanayileşen ülkelerde ortaya çıkmıştır. Kitaba göre, sıklıkla ve çok sayıda basıldı ̆̆ı, dolayısıyla da daha geniş bir okuyucu kitlesine ulaşabildiği için bu süreli yayınlar, mimari düşüncelerin de daha hızl yayılmasını sağlamışlar ve 19. yüzyıl Avrupası'nda mimari söylemlerin üretilmesinin, aktarlmasının ve yaygınlaştırllmasinın en etkin aracı haline gelmislerdir. Türkiye'de ise ilk mimarlı süreli yayınlarl, mimari yazının mimarlık gündemini en etkin biçimde yönlendirdiği 20. yüzyllın ilk yarısında, 1930'ların başlarında yayınlanmaya başlayan Mimar/Arkitekt ile karşılığını bulmuştur. Batılı öncüllerinden farklı olarak, derginin öncelikli hedefi, mimarların birbirleri ile iletişim kuracakları bir platform oluşturmak, dönemin kapsamlı imar faaliyetleri doğrultusunda ülkenin farklı bölgelerinde bulunan genç Türk mimarların mesleki üretimlerinden birbirlerini ve toplumu haberdar etmek, örnek alınan Batı dünyasındaki mimari modernlikleri Türk mimarlarına tanıtmaktır. Mimar/Arkitekt, bir yandan da, genç Türk mimarları için eğitici ve öğretici bir rol üstlenmiş ve yayın hayatını sürdürdüğ̈̈ 50 yıl boyunca da, Türkiye'deki mimarlı kültürünün en önemli temel taşlarından birini tanımlamıştır.

Anahtar Kelimeler: Mimarlık süreli yayınları, 19. yüzyıl, Erken Cumhuriyet dönemi, Mimarlı tarihi, Arkitekt. 


\section{Abstract}

Although the first periodicals appeared in England in the second half of the 17th century; the introduction of the periodicals to the architectural realm occurred a century later. The architectural pioneers of these periodicals emerged in early industrialized countries such as England, Germany and France, where industrialization practices began to radically change the architectural production. According to the book, these periodicals which enabled the spread of architectural ideas more rapidly became the most effective mass medium of producing, transferring and disseminating architectural discourses in the 19th century Europe, as they were published frequently and in large number, and thus could reach a wider audience. But, in Turkey, the first architectural periodicals emerged in 1930s while the architectural discourses have mostly led the architectural agenda in the early 20th century, by the publication of Mimar/Arkitekt. Unlike its Western predecessors, the primary goal of the periodical was to create a platform where architects would communicate with each other, to inform each other and the society about the architectural works of young Turkish architects in different regions of the country and to introduce the architectural modernities in the Western world to the Turkish architects. Mimar/Arkitekt have also played an educational and instructive role for young Turkish architects; and identified one of the most important thresholds of the architectural culture in Turkey during its publication for 50 years.

Keywords: Architectural periodicals, 19th century, Early Republican period, Architectural history, Arkitekt.

\section{Giriş: Mimari Yazın Ortamının Başlangıcına Dair}

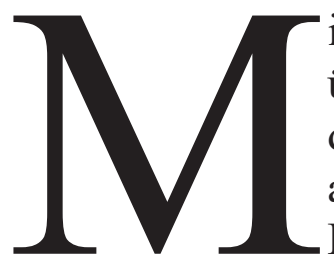

imarlık ortamının mimari yazın ile tanışması, aslında yapı üretim etkinliği kadar eskiye dayanır. Batı dünyasında, mimari düşüncenin yalnızca inşai etkinlikler ile değil, mimari metinler aracılığıyla da ortaya konabileceği inancının öncüsü Vitruvius’un De Architectura'sı olarak kabul edilir. Antik dönemin 'kapsamlı ve ayrıntılı bir elkitabı"' olarak değerlendirilebilecek olan On Kitap, mimarlığın temel ilkelerinden mimarın eğitimine, kentlerden konutlara, dini yapılardan kamusal yapılara, üsluplardan yapı malzemelerine, ince yapı işçiliğinden süslemelere, su yapılarından kullanılan teknik aletlere kadar mimarlığı ilgilendiren 'her şey'den söz eder. Hatta, kitapta ortaya konan ilkeler o kadar etkili olur ki; sonraki yüzyılların mimarlıklarını bile biçimlendirir.

Rönesans'la birlikte Gutenberg matbaasının ortaya çıkışı ve baskı sisteminde geliştirilen yeni teknikler, mimarlık pratiğinin yanında, mimari yazının da bir o kadar etkin bir rol üstlenmesine yol açar. Vitruvius'un yeniden keşfedildiği ve De Architectura'nın yeniden basılarak çoğaltılmaya başlandığı bu dönemde, Alberti'nin “mimarın tamamıla

1 Fikret Yeğül, "Vitruvius ve De Architectura", Mimarlık Üzerine On Kitap (Şevki Vanlı Mimarlık Vakfı Yayınlar1, 2005), xi. 
donatılmış bir tasarımc1 (complete designer) olduğuna dair modern görüşlerini”" içeren De Re Aedificatoria gibi kitaplarının yayınlanması, mimarlığın inşa eyleminden öte yalnızca yazın aracılığıyla da üretilebileceğini gösteren ilk işaretler olur. Modern dünyanın bu yeni düşünce sistemi ise, mimarlık bilgisinin, önceki dönemlere nazaran hızlı bir biçimde yayılmasına ve mimari yazının etki alanının da genişlemesine zemin hazırlar. İzleyen dönemde ise, her ne kadar 17. yüzyıl Avrupası'nın Aydınlanma düşüncesi ile ilgili olarak ilk gazete ve dergiler yayınlanmaya başlamışsa da, mimarlık ortamının süreli yayınlarla karşılaşması ancak endüstrileşme ile bağlantılı olarak gerçekleşecektir.

Endüstrileşme pratiklerinin baskı teknolojilerinde yol açtığ dönüşümler ve her alanda etkili olan hız kavramı, yazın alanında bir takım dönüşümleri beraberinde getirirken; mimari yazın alanını da derinden etkiler. Mimari bilgi ve düşüncelerin o güne kadar görülmemiş bir hızla ve genişlikte yayılmasını sağlayan ilk mimarlık süreli yayınları da, 19. yüzyılın mimari kaos ortamında mimari söylemlerin üretilmesinin, aktarılmasının ve yaygınlaştırılmasının en etkin yolu olarak, mimari pratik içerisinde özel bir 'mecra' (medium) tanımlar. Bu yeni ortam, dönemin mimari olgularının (üsluplarının, biçimlerinin, mimarlarının, yapılarının vb.) birbirlerine üstün gelme yarışında, meşru bir zemin oluşturma çabaları için önemli bir araç olarak görülür. Üstelik bu araçsallaşma, yalnızca mimarlık alanında ve mimarlar arasında değil; daha geniş bir ölçekte, toplumsal alanda da varlık kazanır. Böylelikle, ilk olarak erken sanayileşen Avrupa ülkelerinde ortaya çıkan mimarlık süreli yayınlarının sayısı da, 19. yüzyılda ortaya konmak istenen mimarlıkların ve mimarlık düşüncesinin çoğullaştığı gibi, giderek çoğalır. Hatta, 20. yüzyılda, dönemin mimari kültürünü belirleyen temel olgulardan biri haline gelir.

Bu süreç, Türkiye'deki mimarlık ortamında ise, mimari yazının mimarlık gündemini en etkin biçimde yönlendirdiği 20. yüzyılın ilk yarısında karşılığını bulur ve ilk mimarlık süreli yayını, Avrupa'daki öncüllerine görece oldukça geç bir tarihte, 1930'ların başlarında varlık kazanır. Bu tarihsel gecikme, gerek mimarlık mesleğinin usta-çırak ilişkisi içerisinde yaparak değil de okullarda verilen mesleki bir eğitimle öğrenilmesini tanımlayan ilk mimarlık okulunun geç 19. yüzyılda kurulması, gerekse de mimarlık mesleğinin yalnızca inşai bir etkinlikten öte bir alan tanımlaması ve mimarın bir yapı ustasından öte profesyonel bir meslek adamı olduğuna dair toplumsal düşüncenin yaklaşık yarım yüzyıllık bir süreç içerisinde oluşturabilmesi ile ilintili görünür.

Mimari düşüncenin yanı sıra; mimari üretim, biçimleniş, ifade ve temsilin de yaygın ifadesini bulduğu bu süreli yayınlar, endüstrileşen mimarlık pratiğinde çeşitlenen ve çoğullaşan aktörlerin varlığıyla bağlantılı olarak, zamanla mesleğe farklı biçimlerde eklemlenen farklı okuyuculara hitap edecek şekilde çeşitlenir. Mimarlık disiplinin, yalnızca mimari pratik veya teori ile sınırlandırılamayacak genişlikteki sınırları -veya sınırsızlığl-,

2 Catherine Wilkinson, "The New Professionaslism in the Renaissance", The Architect: Chapters in the History of the Profession, ed. Spiro Kostof (New York: Oxford University Press, 1977), 124. 
aynı zamanda bu süreli yayınların da ilk örneklerinden başlayarak, mimarlığa dair ‘herşey'i kapsayan geniş bir içeriğe sahip olmasına neden olur.

\section{Mimari Yazın Ortamının Değişiminde Dair: İlk Mimarlık Süreli Yayınları}

İlk süreli yayınlar, 17. yüzyılın ikinci yarısında İngiltere'de ortaya çıkmakla birlikte; mimarlık ortamının süreli yayınlar ile karşılaşması daha geç bir tarihte gerçekleşir. Bu kapsamda, süreli yayınların mimarlık alanındaki öncülleri, yaklaşık bir yüzyıl sonra, İngiltere, Almanya ve Fransa gibi erken sanayileşen Avrupa ülkelerinde ortaya çıkar ve 18. yüzyıl, özellikle birçok bilimsel eserin, elkitabının ve kataloğun yayınlandığı İngiltere başta olmak üzere, mimarlık yazının altın çağı olur ${ }^{3}$. Ancak, 18. yüzyıl sonlarında çıkarılan bu yayınlar, isimlerinde yer alan magazine ifadesi ile bağlantılı olarak ilk mimarlık süreli yayınları olarak nitelendirilmekteyse de; bir dergiden ziyade, bir kitap niteliği taşırlar.

Bubağlamda, 1774yılında, John Carter tarafından Londra' da aylık olarak yayınlanmaya başlayan The Builder's Magazine, isminde yer alan magazine ifadesi ile ilişkilendirilerek, ilk mimarlık dergisi olarak değerlendirilen yayınlardan biridir ${ }^{4}$. İlk sayısında da belirtildiği üzere, "mimarlar, marangozlar, taş ustaları, duvar ustaları için olduğu kadar; yapı sanatının ehil uzmanları olmayı arzu eden herkes" için bir elkitabı olma amacını güden dergi (Şekil 1), "en görkemli ve şahane yapılardan en basit ve sade yapılara kadar, her üslup ve zevkteki mimari tasarımları, planları ve kesitleri ile birlikte yayınlayarak saraydan kır evine kadar her çeşit yapının inşasında mükemmel bir yardımcı olarak hizmet etme"yi hedeflemiştir ${ }^{5}$. Dergi, kiliseler, hastaneler ve diğer kamu yapılarından; salon, yemek odası, giyinme odası, yatak odası vb. tüm iç mekânların kapı ve pencere detaylarına; antik Yunan, Roma ve Gotik yapıların plan ve kesitlerinden; park ve bahçeler gibi yeşil alanların tasarımına kadar geniş bir yelpaze sunar. Böylelikle, mimarlığın tüm içeriğini bir bütün olarak ele almasının yanı sıra; bir katedral, konak, tapınak veya bir kır evi vb. inşa etme ehliyetinde olan tüm aktörlere de hitap etme iddiasını taşır ${ }^{6}$. Ancak, dergi, gerek 1778 yılında ulaştığı 628 sayfalık içeriğgi, gerekse de mimari terimler sözlüğü, yapı düzenleri ve oranları, malzeme fiyatları ve işçilik ücretleri gibi konulara yönelik içeriği bağlamında, bir dergiden daha fazlasına, bir kitaba işaret eder?

3 John Wilton-Ely, "The Rise of the Professional Architect in England", The Architect: Chapters in the History of the Profession, ed. Spiro Kostof (New York: Oxford University Press, 1977), 188.

4 Steve Parnell, “Architectural Design, 1954-1972: The Architectural Magazine's Contribution to the Writing of Architectural History" (PhD diss., University of Sheffield School of Architecture, 2011$), 5$.

$5 \quad$ The Builder's Magazine, 1774.

6 The Builder's Magazine, 1774.

$7 \quad$ Parnell, “Architectural Design, 1954-1972: The Architectural Magazine's Contribution to the Writing of Architectural History", 5. 

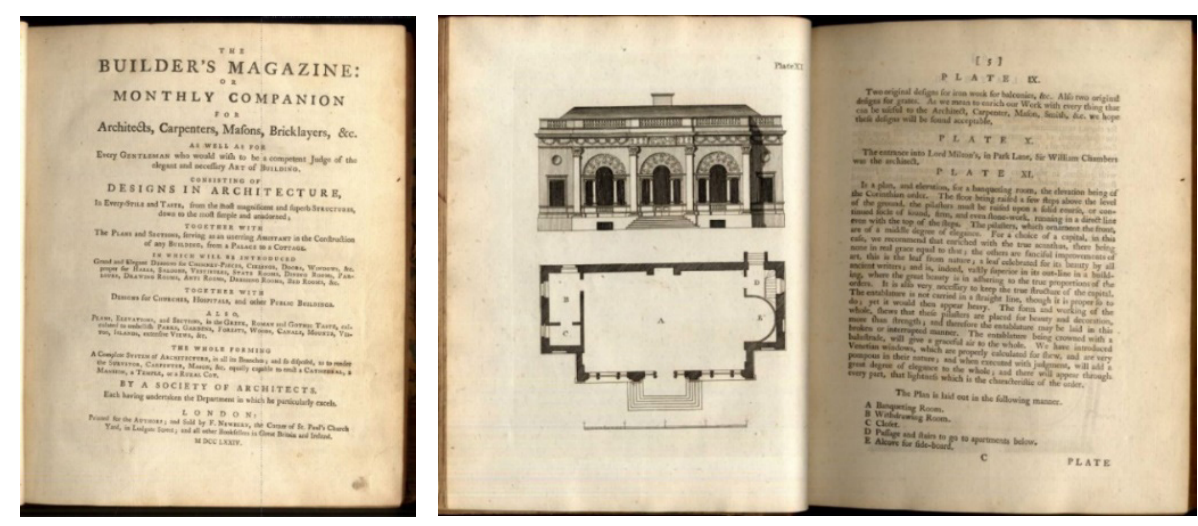

Şekil 1. The Builder's Magazine Dergisinin 1774 Tarihli İlk Sayıs1 ${ }^{8}$

Benzer biçimde, Andreas Böhm tarafından 1777'de Münih'te yayınlanmaya başlayan Magazin für Ingenieur und Artilleristen de, mimari tasarımdan çok, topçu askerlerine yönelik inşaat talimatnamelerine yer veren 400 sayfalık içeriği ile bir kitap niteliği taşı1'. Yine 1789 yılında, Gottfried Huth tarafindan Weimer'da yayınlanmaya başlayan Allgemeines Magazin für die Bürgliche Baukunst, ilk mimarlık dergilerinden biri olarak değerlendirilmekteyse de; isminde yer alan magazin ifadesinden ziyade, 400 sayfalık içeriği nedeniyle bir kitap olarak tanımlanabileceği gibi ${ }^{10}$; aynı zamanda "inşaat etkinlikleri rehberi" olarak da nitelendirilmektedir ${ }^{11}$.

İlk Fransız mimarlık süreli yayını olan Joumal des Bâtiments Civils ise, 25 Eylül 1800 tarihinde Maurice-François-Camille Le Bars tarafından Paris'te yayınlanmaya başlar ${ }^{12}$. Aynı zamanda bir müteahhit olan Camille, derginin bin kopyasını sanatçı ve mimarlara ücretsiz olarak göndermiştir. Camille, ilk sayıda asıl amaçlarının ve arzularının "müteahhitler tarafından kullanılan hammaddelerin günlük fiyatları"nı ele almak olduğunu belirtir ve haftada iki kez yapı malzemelerine ilişkin fiyat listeleri yayınlar ${ }^{13}$. Derginin bu içeriği, hem bir mimar yerine bir müteahhit tarafından yayınlanıyor olması, hem de derginin kökenini oluşturan Almanach des Batiments (Yapılar Almanağı) adlı inşaat meslekleri yılllı̆ı ile ilişkili görünür ${ }^{14}$. Her ay 140 sayfa olarak yayınlanan dergi, üçüncü sayısıyla birlikte değişime gider. Fiyat listeleri ile reklamlar arka sayfalara gönderilirken; yerlerini mesleki duyurular, dönemin mimarlıkları ve mimarlık pratiği üzerine eleştiriler, mimarlık tarihi ve teorisi üzerine yazılar ve tartışmalar alır. Bu yönüyle, dergi, yalnızca mimarlar değil,

8 The Builder's Magazine, 1774.

9 Parnell, “Architectural Design, 1954-1972: The Architectural Magazine's Contribution to the Writing of Architectural History", 5.

10 Parnell, “Architectural Design, 1954-1972: The Architectural Magazine's Contribution to the Writing of Architectural History", 5.

11 Uğur Tanyeli, "Mimarlık Dergisi Neyi Temsil Eder? 20. Yüzyıla Bir Bakış”, Arredamento Mimarlık, sayı 2000/12 (2000): 97.

12 Dergi, sonraki yıllarda Journal des Bâtiments Civils des Monuments et des Arts adını almakla birlikte; daha sonra Annales de l'architecture adıyla yayınlanmaya devam etmiştir. Bkz. Helene Lipstadt, "Early Architectural Periodicals", The Beaux-Arts and Nineteenth-Century French Architecture, ed. Robin Middleton (Thames and Hudson, 1984), 51.

13 Lipstadt, "Early Architectural Periodicals", 51-52.

14 Tanyeli, "Mimarlık Dergisi Neyi Temsil Eder? 20. Yüzyıla Bir Bakış”, 97. 
felsefecilerden bilim insanlarına kadar uzanan genişlikteki okuyucu kitlesi için bir tartışma platformu oluşturur ${ }^{15}$ ve mimarlık alanında yeni bir üretim zemini tanımlamaya başlar.

Lipstadt, Joumal des Bâtiments Civils ile yine eşzamanlı ilk Fransız mühendislik dergisi olan Recueil Polytechnique des Ponts et Chaussées dergisini içerikleri ve amaçları bağlamında karşılaştırır'16. Asıl amacı "kamu binaları, çeşitli sivil inşaatlar ve yolların yapımı ve bakımı; bataklıkların kurutulması; ormanlık ve yeşil alanların ağaçlandırılması; kısaca topluma en yararlı ve en onurlu meslek alanı olan Ponts et Chaussées ile ilgili her şey" olan Recueil, temel olarak mühendislik alanına ve mühendislere odaklanırken, mimarlar ikinci planda tutulmuştur ${ }^{17}$. Tam da bu nedenle, okuyucularına, mimarlık alanını ilgilendiren "estetik teorisi veya yapım teknikleri" ile ilgili bir şey sunmaz; aksine ülke ölçeğinde yeni yollar ve kanallar gibi ulaşım ağlarının inşasıyla, Fransa'nın refahına yönelik "ulusal ve bölgesel ilerleme" için çeşitli gelişim planları yayınlanır ${ }^{18}$. Ancak, bir müteahhit olmasına rağmen, Camille, "çağdaş Fransız mimarisinin estetik ideallerini geliştirme"yi amaç edinerek, "taşradaki yapım faaliyetlerinin geri kalmışlığını düzeltme" arzusuyla19, inşa edilmemiş yarışma projeleri ve hayal kırıklıklarından kaynaklanan "uzun ve nafile tartışmalar"a yer verir ${ }^{20}$. Mimarlığın, inşa etme pratiğinden ziyade bir güzel sanatlar alanı olmasına dayanan bu düşünceye paralel olarak, okuyuculara, mimarlığın sanatsal temeline dayanan çeşitli görüssler sunar ${ }^{21}$. Eşzamanlı iki süreli yayın arasındaki böylesi farklılıklar, sahip oldukları içeriklerinden çok daha öte; yapım etkinliğinin başlıca aktörleri olan mimar ve mühendislerin, birbirinden ayrılmaya ve ayrışmaya başlayan mesleki sınırlarına ve rollerine işaret etmektedir. Sanayileşmenin ve yeni teknolojilerin, büyük ölçüde inşa etme pratiklerini domine ettiği 19. yüzyllın kaotik ortamında, mühendisler profesyonel bir meslek alanı tanımlamak için herhangi bir süreli yayına ihtiyaç duymazken; mimarlık dergileri, temel olarak, profesyonel bir meslek alanı tanımlamanın aracı olarak varlık kazanır.

Camille'e göre de, mimarlık süreli yayınlarının başlıca önemi, "sanat alanında günbegün meydana gelen değişimlerin takip edilmesini sağladığı gibi, bu değişimlere yönelik farklı düşüncelerin ifade edildiği özgür bir tartışma platformu oluşturması"ndan kaynaklanır. Bu yönüyle mimarlık süreli yayınları, "kitap yazamayacak kadar meşgul ve mütevazi, ama oldukça yetenekli" kimseler için kendini topluma tanıtabilme olanağ sağladığ1 gibi ${ }^{22}$; aynı zamanda da bunun en pratik, çabuk ve ucuz yolu olur ${ }^{23}$. Özgün makalelerin veya açıklamaların yayınlandığı bu dergiler, bir yandan mimarlara kamusal görünürlük ve şöhret kazandırırken, bir yandan da düşük bir fiyata, geniş bir bilgi ortamı

15 Lipstadt, "Early Architectural Periodicals", 52.

16 Recueil Polytechnique des Ponts et Chaussées yalnızca 2 cilt olarak 1803 ile 1807 yıllarında yayınlanmıştır. Bkz. Lipstadt, "Early Architectural Periodicals", 54.

17 Lipstadt, "Early Architectural Periodicals", 54.

18 Lipstadt, "Early Architectural Periodicals", 55.

19 Lipstadt, "Early Architectural Periodicals", 52.

20 Lipstadt, "Early Architectural Periodicals", 55.

21 Lipstadt, "Early Architectural Periodicals", 52.

22 Lipstadt, "Early Architectural Periodicals", 53.

23 Lipstadt, "Early Architectural Periodicals", 52. 
sunar.

Yüzyılın ilk yarısında, Loudon tarafindan Mart 1834 tarihinde İngiltere'de yayınlanmaya başlayan The Architectural Magazine, Avusturya'da 1836 yılında yayın hayatına başlayan Allgemeine Bauzeitung, 1840 tarihli Fransız Revue Générale de l'architecture et des Travaux Publics ve 1843 tarihli İngiliz Builder, 1851 tarihli Alman Zeitschrift für Bauwesen gibi mimarlık süreli yayınlarına; yüzyıl sonlarında, daha sanatsal içerikli olan 1893 tarihli The Studio, 1896 tarihli Architectural Review ve 1899 tarihli Berliner Architekturwelt: Zeitschrift für Baukunst, Malerei, Plastik und Kunstgewerbe der Gegenwart gibi dergiler eklenir ${ }^{24}$.

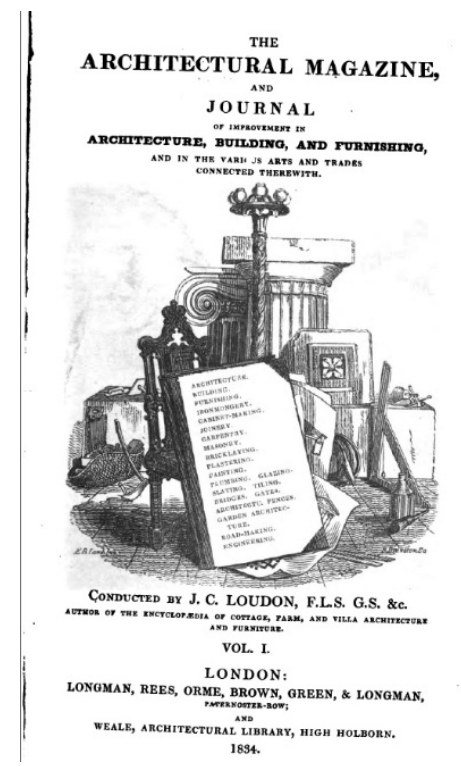

Şekil 2. The Architectural Magazine Dergisinin 1834 Tarihli İlk Sayıs ${ }^{25}$

İngiltere'nin ilk mimarlık süreli yayını olarak tanımlanan, John Claudius Loudon'un editörlüğündeki The Architectural Magazine, ilk sayısının alt başlığında "mimarlık, yapım ve dekorasyon alanındaki ve bununla bağlantılı olarak çeşitli sanat ve ticaret alanlarındaki gelişmeleri” konu edineceğini duyurur (Şekil 2). Bu alanlar ise, "mimarlık, inşaat, dekorasyon, hırdavatçılık, marangozluk, doğramacılık, ahşap işleri, taş işçiliği, duvarcılık, sıvacılık, boyacılık, sıhhi tesisatçılık, cam işçiliği, arduvaz kaplama işçiliği, mozaik döşemeciliği, köprüler, kapılar, çitler, peyzaj düzenlemesi, yol yapımı, mühendislik" olarak ifade edilir ${ }^{26}$. Beş yıl boyunca aylık olarak yayınlanacak olan derginin ${ }^{27}$ ilk cildinin önsözünde, Loudon, derginin amacını "mimarlığa yönelik toplumsal ilgiyi arttırmak, mimarlığı daha entelektüel bir meslek haline getirmek, kadınlar için uygun bir çalışma alanı olarak önermek, genç mimarları görmeye ve çizmeye olduğu kadar okumaya, yazmaya ve

24 Anne Hultzsch \& Catalina Mejía Moreno, "Introduction: Building Word Image, a New Arena for Architectural History", Architectural Histories, 4(1): 13 (2016): 3.

25 The Architectural Magazine, Mart 1834.

26 The Architectural Magazine, Mart 1834.

27 Parnell, "Architectural Design, 1954-1972: The Architectural Magazine's Contribution to the Writing of Architectural History", 7. 
düşünmeye teşvik etmek" olarak belirtir²8.

Loudon'a göre "mimarlığı, özellikle kadınlar olmak üzere, tüm okuyucular için uygun bir meslek alanı" haline getirecek "ilk adım”ı oluşturan dergide, mimarların teknik olarak "mimari tasarımın bileşenleri”" biçiminde tanımladıkları konuları tüm okuyuculara tanıtma amacını güden ve mimar profesyoneller tarafından yazılmış klasik dönem mimarlığı ve Gotik mimarlık üzerine makalelerle birlikte; inşa edilmiş kamu ve özel yapıların tanıtımları ve eleştirileri, dekorasyon önerileri, kırsal alan mimarlığından peyzaj mimarlığına, mobilyadan yapı detaylarına ve mühendisliğe kadar uzanan geniş bir yelpazede makaleler yayınlanır. Ayrıca yıl içerisinde İngiltere, Fransa ve Almanya'daki önemli mimari ürünlerin bilgilerine dair "Değerlendirme" (Review Department) ile yine Avrupa ve Amerika'da yayınlanmış olan mimarlık ürünlerinin isimlerine dair "Katalog" (Catalogue) bölümlerine de yer verilir. "Muhtelif Bölümler"de (Miscellaneous Department) ise, farkl1 yazarlar tarafindan ortaya konan çeşitli düşünceler ve haberlerle birlikte, özellikle İngiltere başta olmak üzere dünyanın her yerinde meydana gelen mimari gelişmeler üzerine eleştiriler yer alir $^{29}$.

Böylelikle, erken sanayileşen Avrupa ülkelerinde, 19. yüzyıl boyunca çok sayıda mimarlık dergisinin yayınlanmaya başlamasıyla birlikte, mimarlık mesleği de, kendine yeni bir mesleki pratik alanı tanımlamış olur. 20. yüzyıl başlarında ise, fotoğraf gibi görsel temsil araçlarının, seri baskı tekniklerinin hakim olduğu yayıncılık sektöründe kullanılmasıyla birlikte; dergilerin yayınlanması, bir yandan gravür baskı tekniklerinin kullanıldı̆̆ı önceki dönemlere göre kolaylaşırken, bir yandan da fiyatları ucuzlamaya başlar. Gri tonlu, hatta renkli fotoğrafların kullanımıyla üretilen yeni temsil biçimleri ise, mimari üsluplar, mimari hareketler ve teorileri yaymak ve yaygınlaştırmak için süreli yayınları araç olarak kullanan mimarlık ortamında da karşılığını hızla bulur ve mimari yayıncılık alanında büyük ilgi çeker ${ }^{30}$. Mimari üretimlerin yalnızca sözcükler değil; aynı zamanda gerçek görsellerle de temsil ediliyor ve bu temsilin de hızla yayılabiliyor ve görsellerin mimari ifade olarak yeniden üretilebiliyor oluşu ise, yüzyıl başlarında "öncü bir sanatsal/tasarımsal/mimari” söylem iddiasındaki ${ }^{31}$ çeşitli mimari akımlar tarafından hızla kabul görmüştür. Eş zamanlı ortaya çıkan modern hareket başta olmak üzere, bu dönemde, "mesajını sadece metinsel değil, grafik araçlarla da iletmeye özen gösteren" ve kendi söylemine "kamuoyu önünde bir meşruiyet zemini oluşturmaya" çalışan mimari gruplar tarafından yeni süreli yayınlar yayınlanmaya başlamıştır ${ }^{32}$. 1917 tarihli De Stijl ve 1920 tarihli Le Corbusier'in L'Esprit Nouveau'sı gibi bu dergiler, herhangi bir ekonomik kaygı taşımamaları nedeniyle ürün tanıtımına yer vermekten özellikle kaçınmışlar, yalnızca kendi yaklaşımları bağlamında reklam ve tanıtım amaçlı olmayan bazı ürünleri ortaya koymuşlardır. Uluslararası ölçekte bir okuyucu kitlesine hitap eden bu yeni süreli yayınların, önceki yüzyıldaki mimarlık

28 The Architectural Magazine, Mart 1834.

29 The Architectural Magazine, Mart 1834.

30 Hultzsch \& Moreno, "Introduction: Building Word Image, a New Arena for Architectural History", 3.

31 Uğur Tanyeli, “Mimarlık’ın 300. Sayısı ve Sektörün Tarihi Bağlamında Bugün Türkiye'de Mimarlık Dergiciliği", Mimarlık, sayı 300 (2001): 34.

32 Tanyeli, "Mimarlık’ın 300. Sayısı ve Sektörün Tarihi Bağlamında Bugün Türkiye'de Mimarlık Dergiciliği”, 34. 
süreli yayınlarından en temel farkı, tamamen manifester bir söyleme sahip olmalarıdır ${ }^{33}$. $\mathrm{Bu}$ bağlamda, mesleki bilgi sınırlarının, değerlerin ve ideolojilerin tartışıldığ 1 bir üretim alanı olan mimarlık dergileri, aynı zamanda mesleğin kuramsal olarak inşa edildiği bir alan haline gelir ki; bu inşayı belirleyen de yine o dönemde dergilerde tartışılan bilgi sınırları, değerler ve ideolojiler olur ${ }^{34}$.

Bu doğrultuda, Batı dünyasında 19. yüzyıl ortalarından itibaren mimarlık pratiğinin kendisini yapı üretiminde rol oynayan diğer mesleki alanlardan ayrıştırmasının bir aracı olarak gündemi belirlemeye başlamış olan mimarlık süreli yayınları, görsel malzemelerin yeniden üretimi ve kullanımının yanı sıra, baskı tekniklerinin ve seri üretim hızının sağladığ olanaklarla birlikte 20. yüzyılda daha geniş bir coğrafi ölçeğe yayılır.

\section{Türkiye'nin İlk Mimarlık Süreli Yayınları ve Mimar/Arkitekt}

Gutenberg matbaası ve bask1 teknolojisinin, Batı dünyasında 15. yüzyılda ortaya çıkışıyla birlikte yazın alanında yol açtığı dönüşümler, Osmanlı dünyasında oldukça geç bir tarihte gerçekleşmiştir. Her ne kadar, matbaa, Osmanlı dünyasına erken 18. yüzyılda Batı'dan transfer edilmişse de; bu teknolojilerin Osmanlı gazete ve süreli yayınları için kullanılması ancak 19. yüzyılda gerçekleşecektir. Yüzyıl başlarında II. Mahmud'un ve devamında Tanzimat'ın moderneleştirmeci politikalarının etkisiyle, tıpkı diğer toplumsal alanlarda olduğu gibi, gazeteler ve dergiler gibi yayıncılık faaliyetlerinde de Batı dünyasında örnek alınmış; böylelikle dönemin Batılılaşmacı anlayışı çerçevesinde, Tanzimat aydınları tarafından, Batı'daki fen ve pozitif bilimlerdeki gelişmelerle ilgili olarak toplumu bilgilendirmek ve bilinçlendirmek amacıyla çeşitli dergiler yayınlanmaya başlamıştır. Ancak, Batı dünyasında, gazete ve dergiler, genellikle özel girişimler tarafından yayınlanırken; Osmanlı dünyasında, iç dinamikleri ile ilintili olarak, bu yayıncılığın öncülüğü imparatorluk tarafından gerçekleştirilir.

Özellikle Fransız dergi ve gazetelerinin örnek alındığı Osmanlı yayıncılığında, ilk Osmanlı gazetesi olan 1831 tarihli Takvim-i Vekâyi'den sonra; ilk dergiler de, yine Fransa' daki eğitim sistemi örnek alınan tıp alanında ortaya çıkar. Vakâyi-i Tıbbiye, 26 Mart 1849 tarihinde, Fransızca ve Türkçe olmak üzere, iki ile dört sayfa halinde yayınlanmaya başlar; ancak 600 abonesi olan dergi, üç yıl sonra kapanır³. Yüzyılın ikinci yarısında, özellikle 1860'lı ve 1870'li yıllarda, Osmanlı süreli yayınlarının sayılarında meydana gelen artışla birlikte; dergilerin alanları da askeri, eğitim, ekonomi, edebiyat, tarih, felsefe, coğrafya, sosyal meseleler, hikayeler, moda, ev hayatı vb. gibi geniş bir yelpazeye ulaşır. Ayrıca, bu dönemde, kadın dergileri, çocuk dergileri, karikatür dergileri gibi özelleşmiş okuyucu kitlesine yönelik çeşitli süreli yayınlar çıkarılmışsa $\mathrm{da}^{36}$; henüz mimarlık alanı ile

33 Tanyeli, "Mimarlık’ın 300. Sayısı ve Sektörün Tarihi Bağlamında Bugün Türkiye'de Mimarlık Dergiciliği", 34.

34 Parnell, "Architectural Design, 1954-1972: The Architectural Magazine's Contribution to the Writing of Architectural History", 3.

35 Kenan Demir, "Osmanlı'da Dergiciliğin Doğuşu ve Gelişimi (1849-1923)”, Iğdır Üniversitesi Sosyal Bilimler Dergisi, say1 9 (Nisan 2016): 77-78.

36 Demir, “Osmanlı'da Dergiciliğin Doğuşu ve Gelişimi (1849-1923)", 71-112. 
ilgili bir dergiden söz etmek mümkün değildir.

Batı dünyasında, ilk mimarlık süreli yayınlarının 18. yüzyıl sonlarında ortaya çıkmasına rağmen, Osmanlı dünyasında -19. yüzyıl sonlarında bile- mimarlık süreli yayınlarının varlık kazan(a)maması, aslında Osmanlı'nın geleneksel mimarlık ortamı ve mimar kimliği ile ilişkili görünür. Batı'da, mimarlık ortamı, daha Rönesans'tan itibaren modern pratikler çerçevesinde biçimlenmiş ve sanatçı kimliği ile bağlantılı olarak, mimar da yaratıcı birey/ modern özne haline gelmiştir. Mimari üretimlerini yalnızca inşa etme eylemi ile değil; mimari düşünce ve söylemleri ile de ortaya koyan mimarlar, mesleki etkinliklerini, Aydınlanma düşüncesinin sorgulama, tartışma, geliştirme gibi modern nosyonları çerçevesinde gerçekleştirmişlerdir. Mimar öznelerin, birbirinden farklı mimarlıklar üretilebileceği farkındalığına yol açan bu durum, söz konusu farklı üretimlerin öncelikle düşünsel ve sonra pratik olarak yaygınlaştırılmasına yönelik uğraşları da beraberinde getirmiştir. Batı'da mimarlık süreli yayınları, böylesi farklı mimarlıklar üzerine tartışmaların bir sonucu olarak varlık kazanırken; Osmanlı dünyasında, bu dönemde henüz ne modern bir özne olarak mimar kimliğinden ne de mimari üretimin modern dinamiklerinden söz etmek mümkün değildir. Halen geleneksel örüntülerini sürdürmekte olan Osmanlı dünyasında, mimarlık, profesyonel bir meslek alanından ziyade, inşa etme eylemi ile özdeş bir alana işaret etmektedir. Özdeştir; çünkü mimarlık, kurumsallaşmış bir meslek eğitimi veren mimarlık okullarında değil; usta-çırak ilişkisiyle yaparak öğrenilir. İmparatorluk sınırları içerisindeki tüm mimari etkinlikler, 19. yüzyıl başlarına kadar saraya bağlı Hassa Mimarlar Ocağı -devamında Ebniye-i Hassa Müdürlügüu- tarafından gerçekleştirilir. Dolayısıyla, Osmanlı dünyasında mimari pratik, Batı'daki gibi birey-özneler tarafından tasarlama düşüncesiyle gerçekleştirilmediği gibi; mimari eğitim de çırağın, ustasından gördüklerini mütemadiyen tekrar ve tekrar inşa ederek usta olmasına dayanır. Mimari üretimin, inşai uygulama ile belirlendiği Osmanlı dünyasında da, bu nedenle mimari söylem üretilemediği gibi; mimari yazın da yalnızca birkaç kitapla sınırlı kalmıştır.

Diğer taraftan, sanayileşmeyle birlikte Batı kentlerinde ortaya çıkan yeni toplumsal koşullar tarafından belirlenen yeni gereksinimler ve bu gereksinimlerin mekânsal üretimlerine dair problemli sürecin yanı sıra, mühendisler ve mimarlar arasındaki mesleki sınırların ayrışmasının yol açtığı düşünsel kaygı ve üretimler de Osmanlı dünyasında görülmez. Bu nedenle, 19. yüzyıl Avrupası’ndaki mimari tartışmaların ortaya koyduğu farklı görüş ve ideolojilerin yayılmasının ve yaygınlaşmasının bir aracı olarak ortaya çıkan mimarlık süreli yayınları da, henüz bir mimarlık söyleminin oluşmadığı Osmanlı dünyasında varlık kazanacak bir zemin bulamaz. Bu zemin, ancak yüzyıl sonunda, 1883 yılında Sanayi-i Nefise Mektebi’nde düzenli bir sivil mimarlık eğitiminin başlamasından sonraki süreçte oluşacaktır. Kurumsal mimarlık eğitimi alan ilk mezunlarını 1889 yılında veren okulun, askeri mühendislik eğitiminin verildiği Mühendishane ve -Mühendishane ile bağlantılı da olsa- sivil mühendislik eğitiminin verildiği Hendese-i Mülkiye' den yaklaşık yüzyıl sonra kurulması, aynı zamanda ilk kez mesleki etkinlik alanı tanımlı bir mimar topluluğunun oluşumuna işaret etse de; bu durum, Osmanlı dünyasındaki ilk mimarlık süreli yayınlarının, ancak erken 20. yüzyılda mühendislerle dayanışma içerisinde ortaya 
çıkmasına yol açacaktır.

Bu bağlamda, Osmanlı dünyasında, mimarlığa ilişkin ilk süreli yayınlar, 20. yüzyıl başlarında, II. Meşrutiyet'in sağladığı özgürlükçü ortamda varlık kazanır. Osmanlı coğrafyasındaki mimarlar ve mühendisler arasındaki etkileşimi ve iletişimi sağlama amacındaki Osmanlı Mühendis ve Mimar Cemiyeti Mecmuası, mimar ve mühendislerin bir araya gelerek, kurumsal nitelikte -bugünkü anlamıyla- bir meslek odası kurma girişimlerinin sonucu olarak yayın hayatına başlar. Mimar Kemaleddin'in ${ }^{37}$ "müntesibîn-i fenni ittihada davet" ederek Tanin gazetesinde verdiği ilanla yaptığı çağrıyla bir araya gelen "erbab-i fünun", 28 Ağustos 1908 tarihinde Sirkeci İstasyon Bahçesi'nde toplanır ve Osmanlı Mühendis ve Mimar Cemiyeti adıyla bir birlik kurarlar ${ }^{38}$. Cemiyetin 18 Eylül 1908 tarihinde Taksim Bahçesi içerisindeki dairede yaptığı toplantı sonucunda hazırlanan yönetmeliğinde ${ }^{39}$, cemiyetin kuruluş amaçları arasında yer verilen "bayındırlık ve mimarlığın gelişmesine çalışmak, mühendisliğe ve mimarlığa ait inceleme ve bilimsel araştırmalar yapmak, mühendis ve mimarlar arasında dostluk ve bağlılığı artırmak, mühendislik ve mimarlığın gelişmesine ve yükselmesine hizmet eden şahısları, bilgisi, ehliyeti ve doğruluğu ile sivrilmiş ve şöhret yapmış müteahid ve işçileri memlekete tanıtmak" ${ }^{40}$, aynı zamanda bir süreli yayının çıkarılması açısından da belirleyici olur.

İçtüzüğünde, etkinlik alanı, mühendislik ve mimarlık ile ilgili her konu olarak belirlenmekle birlikte; benzer nitelikteki diğer Osmanlı ve yabancı cemiyetler ile kurulacak ilişkiler aracılığıyla karşılıklı yayın değişimlerinde bulunmak, çeşitli konferanslar ve yarışmalar düzenlemek ve bir süreli yayın çıkarmak da cemiyetin hedefleri arasında yer alır ${ }^{41}$. Bu bağlamda, cemiyetin nizamnamesinin 76. maddesinde, "mühendislik ve mimarlığa ait fennî bir risale-i mevkute" olarak ifade edilen ${ }^{42}$ süreli yayın, kuruluşundan bir yıl sonra, Ekim 1909 tarihinde, Osmanlı Mühendis ve Mimar Cemiyeti Mecmuası adıla aylık olarak yayınlanmaya başlar ${ }^{43}$. Eylül 1910 tarihine kadar, 12 sayı yayınlanan dergide, "matematik, fizik, makine, elektrik bilgileri, ilm el-maaden (mineraloji), bayındırlık, sanayi, mimarlık ve inşaat-1 miyahiye (su mühendisliği)" konularında çeşitli yazılara yer verilir ${ }^{44}$. Bu yazılar,

37 Kemaleddin Bey, bu sırada Evkaf Nezareti'nin yanı sıra, Hendese-i Mülkiye Mektebi'nde de görev yapmaktadır.

38 Feza Günergun, “Osmanlı Mühendis ve Mimarları Arasında İlk Cemiyetleşme Teşebbüsleri”, Osmanlı Mühendis ve Mimar Cemiyeti Belgeleriyle (Ankara: TMMOB Mimarlar Odası Ankara Şubesi, 2008), 44.; Cüneyd Okay, "Osmanlı Mühendis ve Mimar Cemiyeti ve Belgeler", Osmanlı Mühendis ve Mimar Cemiyeti Belgeleriyle (Ankara: TMMOB Mimarlar Odası Ankara Şubesi, 2008), 77.; Çetin Ünalın, Cumhuriyet Mimarlığının Kuruluşu ve Kurumsallaşma Sürecinde Türk Mimarlar Cemiyeti’nden Mimarlar Derneği 1927’ye (Ankara: Mimarlar Derneği 1927, 2002), 16.

39 Feza Günergun, "Son Osmanlı Döneminde Mimar ve Mühendis Meslek Örgütleri ve Dergileri", Mimarlik, say1 300 (2001): 26.

40 Günergun, "Osmanlı Mühendis ve Mimarları Arasında İlk Cemiyetleşme Teşebbüsleri”, 46-47.

41 Günergun, "Son Osmanlı Döneminde Mimar ve Mühendis Meslek Örgütleri ve Dergileri”, 26.; Günergun, "Osmanlı Mühendis ve Mimarları Arasında İlk Cemiyetleşme Teşebbüsleri", 48.

42 Okay, "Osmanlı Mühendis ve Mimar Cemiyeti ve Belgeler", 78.

43 İlk sayıları 24 sayfa olarak yayınlanan derginin 4. sayısında, gördüğü ilgi nedeniyle derginin 32 sayfaya çıkarıldığı belirtilir. Bkz. Günergun, "Osmanlı Mühendis ve Mimarları Arasında İlk Cemiyetleşme Teşebbüsleri”, 51.

44 Günergun, derginin yayın hayatına son vermesiyle birlikte, cemiyet üyelerinin yazılarının, Osmanlı Mühendis Iktisad Cemiyeti tarafından 1908-1914 yılları arasında çıkarılan Genç Mühendis dergisinde 
cemiyetin yönetmelikleri, etkinlikleri, üye listeleri, gelen mektuplar ve dergiye ait haberleri içeren "kısm-1 idari" ve bilimsel makaleler, bilim ve teknikteki yeni buluşlara ilişkin haberleri içeren "kısm-1 fenni” olarak iki bölüm halinde yayınlanır"5 .

$\mathrm{Bu}$ tarihlerde, cemiyetin üyelerinin yalnızca \%33'ünün mimarlardan, geri kalan çoğunluğun ise mühendislerden meydana gelmesi ile ilişkili olarak; dergide, çoğunlukla, mühendis okulları ve öğretim programı, kara ve demiryolu yapımı, köprü yapımı, arazi haritalarının hazırlanması, inşaat teknikleri gibi daha çok mühendislik alanına ilişkin yazılar yayınlanır. Günergun'un ${ }^{46}$ ve Okay'ın ayrıntılı biçimde verdiği içeriğine göre ${ }^{47}$; dergide, mimarlık alanı ile ilgili tek yazı, 7. sayıdan 11. sayıya kadar bir dizi halinde yayınlanan Mimar Kemaleddin'in "Mimar-î İslâm” başlıklı yazısıdır"4. Bunun dışında, tüm sayılar boyunca yayınlanan yazıların tamamı mühendislik alanına ilişkindir.

I. Dünya Savaşı yıllarında faaliyetleri kesintiye uğrasa da, 1919 yılında tekrar kurulan cemiyet, aynı yıl Osmanlı Mühendis ve Mimar Cemiyeti Salnamesi adıyla bir yıllık yayınlama kararı alır. Ancak, Günergun’a göre yapılan çağrıya rağmen hiçbir makalenin gelmemesi üzerine, Okay'a göre ise yazılar toplanmış olmasına rağmen, salname yayınlanmaz ${ }^{49}$. Bir yıl sonra, 1920’de, mühendislik ve mimarlık tarihi ile ilgili başka bir salnamenin yayınlanmas1 kararlaştırılmış, mühendis ve mimarlardan belge ve fotoğraflar göndermeleri istenmişse de, bu salname de yayınlanamamıştır ${ }^{50}$. Bu sırada, cemiyet tarafından tekrar bir süreli yayın çıkarılmaz; ancak 14 Nisan 1922 tarihinden itibaren bir yıl boyunca 18 sayı olarak yayınlanan Mühendis Mektebi Mecmuası'nın ilk 9 sayısında “Osmanlı Mühendis ve Mimar Cemiyeti'nin Naşir-i Efkarıdır” ifadesine yer verildiği görülmektedir ${ }^{51}$. Bu doğrultuda, Günergün'ün araştırmasında ayrıntılı bir biçimde yer verdiği her sayının içeriğine göre ${ }^{52}$; dergideki yazıların tamamı şimendifer, makineler, betonarme hesapları, kemer açıklıkları hesapları, kafes kirişlerin uygulanması, rutubetin beton üzerindeki etkisi, çatı makasları, mukavemet hesapları gibi mühendislik alanına ilişkindir. Ayrıca, tekrar kurulan cemiyete ilk

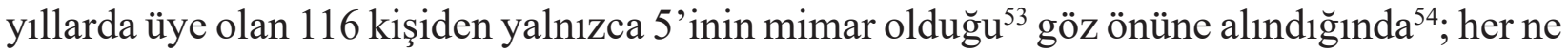

yayınlanmaya devam ettiğini belirtir. Bkz. Günergun, "Osmanlı Mühendis ve Mimarları Arasında İlk Cemiyetleşme Teşebbüsleri”, 51, 60. Bu bağlamda, Mühendis Mektebi öğrencileri tarafından hazırlanan derginin, yalnızca mühendislik alanı ile ilişkili olması nedeniyle, mimarlık süreli yayınları arasında değerlendirilmesi doğru olmayacaktır.

45 Günergun, “Osmanlı Mühendis ve Mimarları Arasında İlk Cemiyetleşme Teşebbüsleri”, 48-49.

46 Günergun, “Osmanlı Mühendis ve Mimarları Arasında İlk Cemiyetleşme Teşebbüsleri”, 67-70.

47 Okay, “Osmanlı Mühendis ve Mimar Cemiyeti ve Belgeler”, 146-150.

48 Kemaleddin'in Bey’in “Mimar-î İslâm” başlıklı yazı dizisi, Nisan 1910, Mayıs 1910, Haziran 1910, Temmuz 1910 ve Ağustos 1910 tarihli sayılarda yayınlanmıştır. Bkz. Günergun, "Osmanlı Mühendis ve Mimarları Arasında İlk Cemiyetleşme Teşebbüsleri”, 68-69.

Günergun, “Osmanlı Mühendis ve Mimarları Arasında İlk Cemiyetleşme Teşebbüsleri”, 59. ; Okay, “Osmanlı Mühendis ve Mimar Cemiyeti ve Belgeler”, 80.

50 Günergun, “Osmanlı Mühendis ve Mimarları Arasında İlk Cemiyetleşme Teşebbüsleri”, 60.

51 Feza Günergun, "Osmanlı Mühendis ve Mimarları Arasında İlk Cemiyetleşme Teşebbüsleri”, Ek5, Cumhuriyet Mimarlı̆̆ının Kuruluşu ve Kurumsallaşma Sürecinde Türk Mimarlar Cemiyeti’nden Mimarlar Derneği 1927’ye (Ankara: Mimarlar Derneği 1927, 2002), 258.

52 Günergun, “Osmanlı Mühendis ve Mimarları Arasında İlk Cemiyetleşme Teşebbüsleri”, Ek-5, $266-268$.

53 Günergun, “Osmanlı Mühendis ve Mimarları Arasında İlk Cemiyetleşme Teşebbüsleri”, 56-57.

54 Üye listesinin 1. numaralı kaydı Kemaleddin Bey’e aittir. Bkz. Günergun, “Osmanlı Mühendis ve 
kadar, dergi, Osmanlı Mühendis ve Mimar Cemiyeti'nin yayını olarak ifade edilmekteyse de, bir mimarlık süreli yayını olarak değerlendirilmesi doğru olmayacaktır.

$\mathrm{Bu}$ yıllarda, Batılı öncüllerine rağmen, Osmanlı dünyasında mimarlık alanına özgü bir süreli yayının olmayışı, dönemin mimari eğitim ve üretim ortamının yanı sıra; dönemin toplumsal yapısı ile de ilişkili görünür. $\mathrm{Bu}$ dönemde, ülkede mimarlık eğitimi veren tek okul olan Sanayi-i Nefise Mektebi'nin kuruluşundan Cumhuriyet yıllarına kadar yaklaşık 190 mimar mezun olmakla birlikte ${ }^{55}$; bu mezunların, neredeyse tamamına yakını gayrimüslimlerden oluşmaktadır ${ }^{56}$. Devletin ve özel işverenlerin daha çok yabancı ve gayrimüslim mimarlara yönelik teşvikinin yanı sıra, 20. yüzyıl başlarında ülkenin içerisinde bulunduğu uzun savaş yılları nedeniyle inşai faaliyetlere yatırım yapılamaması ile ilişkili olan bu durum ${ }^{57}$, ancak erken Cumhuriyet yıllarının modernleşme projesiyle birlikte başlatılan imar faaliyetleri ile değişime uğrayacaktır. 1924 yılından sonra, okulun mezunları arasındaki Türk mimar sayılarında artış olduğu gibi, 24 kişiyle en çok mezun 1928 yılında verilmiştir ${ }^{58} .1928$ yılı mezunları ise, ülkede bir mimarlık ortamının oluşturulması ve özellikle mimarlık süreli yayınlarının ortaya çıkışı için de önemli katkı sağlayacaklardır.

Diğer taraftan, bu dönemde, başkent Ankara başta olmak üzere, ülke genelinde yoğun bir imar faaliyetine başlanmış ve bu amaçla Avrupa'dan çok sayıda yabancı mimar davet edilmiştir. Bu yıllarda, bir yandan Anadolu kentlerinin modernleştirilmesi ve yeni modern yerleşimlerin kurulması amacıyla Batılı uzmanlar getirilirken, bir yandan da Nefise Mektebi'nin öğretim programında önemli değişiklikler gerçekleştirilmiştir. Öncelikle okulun adı, Devlet Güzel Sanatlar Akademisi olarak değiştirilmiş, Mimarlık Bölümü’ne yalnızca lise mezunlarının kabul edilmesi, eğitim süresinin dört yıl olarak belirlenmesi ve mezunlarının yüksek dereceli öğrenim görmüş sayılması yolunda kararlar alınmışıır ${ }^{59}$. 1928 yılında Guilio Mongeri'nin ve 1930 yılında da Vedat Bey'in istifasıyla, Mimarlık Bölümü'nün yürütücülüğüne, Avrupa modernizminin de ülkedeki öncülerinden olan Ernst Egli getirilmiş; Arif Hikmet Holtay ile okulun 1928 yılı mezunları arasında yer alan Sedad Hakkı Eldem ve Seyfettin Arkan da, asistan olarak görevlendirilmiştir ${ }^{60}$. Ayrıca, 1927 yılında çıkarılan bir kanunla, mimar ve mühendis ünvanlarının kullanımına kısıtlama getirilmiş, bu tarihten sonra yalnızca resmi mesleki eğitim almış ve Türkiye veya yabancı bir ülkede eşdeğer mimarlık okulları mezunlarının mimar ünvanını kullanmaları kararlaştırılmıştır ${ }^{61}$.

Mimarları Arasında İlk Cemiyetleşme Teşebbüsleri”, 56-57.

55 I. Dünya Savaşı'nın başladığı 1914 yılından, Cumhuriyet'in ilanına kadar olan sürede, mevcut savaş ortamı ile ilişkili olarak, her yıl yalnızca birkaç mimar mezun olmuştur. Bkz. Yekta Özgüven, "Türkiye'de Kadın Mimar Kariyerinin Başlangıcı (1934-1960)" (Yüksek Lisans Tezi, Yıldız Teknik Üniversitesi Fen Bilimleri Enstitüsü, 2002).

56 Özgüven, “Türkiye’de Kadın Mimar Kariyerinin Başlangıcı (1934-1960)”.

57 Gülsüm Baydar, Osmanlı-Türk Mimarlarında Meslekleşme (Ankara: TMMOB Mimarlar Odası Yayınları, 2012), 13.

58 Özgüven, “Türkiye’de Kadın Mimar Kariyerinin Başlangıc1 (1934-1960)".

59 Mustafa Cezar, Devlet Güzel Sanatlar Akademisi'nin 90. Yll, (İstanbul: Devlet Güzel Sanatlar Akademisi, 1973).

60 Sibel Bozdoğan, Modernizm ve Ulusun İşası Erken Cumhuriyet Türkiyesi’nde Mimari Kültür (İstanbul: Metis Yayınlar1, 2012), 175-176.

61 Baydar, Osmanlı-Türk Mimarlarında Meslekleşme, 64. 
Modern mimarinin ülkeye girdiği bu yıllarda, mezun olan Türk mimarların sayıları arttığı gibi, sürdürülen imar faaliyetleri ile bağlantılı olarak, mimari etkinlik alanları da ülke geneline yayılmıştır. Bu nedenle, başta çok sayıda Türk mimarın aralarında bulunduğu 1928 yılı mezunları olmak üzere, dönemin genç Türk mimarları, ülkedeki yabancı mimarların etkinlikleri ile rekabet edebilme kaygısıyla, aralarında iletişim kurmak, etkinliklerini tanıtmak ve bilgilen(dir)mek, mimari faaliyetlerinden haberdar olmak isteğiyle bir birlik oluşturma ihtiyacı duymuşlardır. Bu bağlamda, Türkiye'nin ilk mimarlık süreli yayını olan Mimar da, mimarlık alanında iletişim sağlayacak bir ortam olarak yayın hayatına başlamıştır.
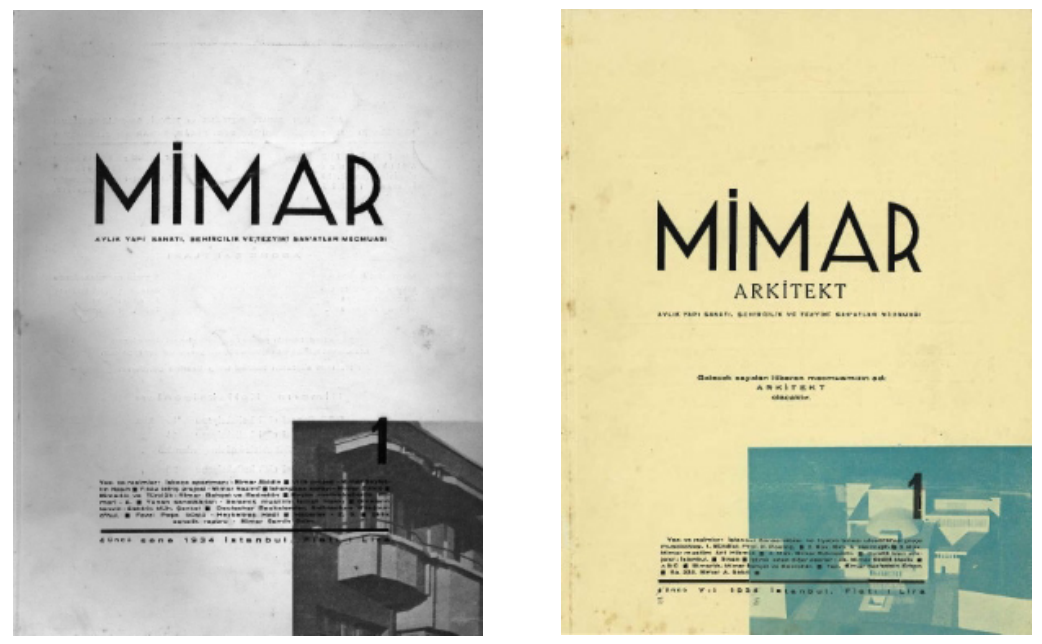

Şekil 3. Mimar ve Arkitekt Dergisinin Kapağ $1^{62}$

$\mathrm{Bu}$ iletişim ve haberdar olma çabalarının ilk adımlarını, 18 Şubat 1927 tarihinde Ankara'da kurulan Türk Mimarlar Cemiyeti ile 09 Mart 1927 tarihinde İstanbul'da kurulan Güzel Sanatlar Birliği ${ }^{63}$ Mimari Şubesi tanımlar ${ }^{64}$. Aralarında Seyfi Arkan, Şevki Balmumcu ve Sedad Hakkı Eldem gibi isimlerin bulunduğu genç Türk mimarların İstanbul'da bir araya gelmeleriyle ortaya çıkan bu oluşumun başlıca amaçları arasında, dönemin modernist düşüncesine paralel biçimde, yeni ve modern mimar kimliğini tanımlamak, profesyonel mesleki sınırları belirlemek ve yeni mimariyi oluşturmak gibi modernist söylemin inşa edilmesi yer alır ${ }^{65}$. Bu modernist söylemin ortaya konulmasında büyük rol oynayacak olan Mimar dergisi de, Zeki Sayar, Abidin Mortaş ve Abdullah Ziya Kozanoğlu tarafından ${ }^{66}$

\section{Mimar (1934): kapak. Arkitekt (1935): kapak.}

63 Güzel Sanatlar Birliği’nin kökeni, 1909 yılında kurulan Osmanlı Ressamlar Cemiyeti’ne dayanmakla birlikte; 09 Mart 1927'de mimari, resim, heykel ve tezyin olmak üzere dört şubeye ayrılmıştır. Bkz. Çetin Ünalın, “Türk Mühendis ve Mimar Odaları Birliği Kanununun Yasalaşması", Mimar.ist, sayı 51, (2014), 58.

64 Çetin Ünalın, Cumhuriyet Mimarlı̆̆ının Kuruluşu ve Kurumsallaşma Sürecinde Türk Mimarlar Cemiyeti’nden Mimarlar Derneği 1927'ye, 24.

65 Bozdoğan, Modernizm ve Ulusun Inşası Erken Cumhuriyet Türkiyesi’nde Mimari Kültür, 176.

66 Devlet Güzel Sanatlar Akademisi 1928-29 yılları mezunlarından, aralarında Zeki Sayar, Samih Akkaynak, Sedad Hakkı Eldem, Feridun Çeçen, Cemil Bey ve Şevki Balmumcu'nun da bulunduğu bir grup genç mimar, 1930 yılında Akademi yıllarında okul dergisini yayına hazırlayan Abidin Mortaş ve öğrenciliği sırasında gazetecilik yapmış olan Abdullah Ziya Kozanoğlu’nun önderliğinde, bir dergi yayınlama amacıyla bir araya gelmişler; toplantılar sonucunda; Mortaş ve Kozanoğlu'nun derginin yayına hazırlanması ve baskı işlerinden, Sayar'ın mali işlerden ve diğerlerinin de yazı ve doküman sağlamaktan sorumlu olmasına karar verilmiştir. Bkz. Zeki Sayar, "25inci Yılı Bitirirken”, Arkitekt, say1 4, (1955), s. 
1931 yılında aylık olarak yayınlanmaya başlar ${ }^{67}$. Bir yıl sonra Kozanoğlu'nun Adana'ya ve Mortaş'1n da 1942'de Ankara'ya gitmesiyle birlikte ${ }^{68}$; Sayar, 1980'lere kadar yaklaşık 50 yıl boyunca, dergiyi tek başına yürütür. Böylelikle, Mimar, Türkiye'nin ilk bağımsız mesleki mimarlık süreli yayını olduğu gibi, aynı zamanda da en uzun soluklu mimarlık süreli yayını olur (Şekil 3).

Dergi, Güzel Sanatlar Birliği’nden bağımsız olarak yayınlanıyorsa da; birliğin Mimari Şubesi, dergiye olan desteğini devam ettirmiş ve derginin özellikle ilk sayılarında sıklıkla şubenin etkinliklerine ilişkin haberler yayınlanmıştır (Şekil 4). Genel Sekreter Ö. Faruk Galip, ilk sayısında, şubenin, derginin yayınlanmasını büyük bir sevinçle karşıladığını, "bir meslek ve sanat mecmuasının çıktığını haber verme" amacıyla, şubenin derginin basılı sayılarının büyük bir kısmını alacağını ve "Türk dünyasının her köșesindeki memleket büyüklerine, idarecilerine ve meslek arkadaşları"na göndereceğini belirtir ${ }^{69}$. Aynı zamanda, Türk mimarlarına, "Türk mimarlık sanatının yetkili tek dili” olarak tanımladığı Mimar'ın etrafinda toplanmaya, derginin yayınlanabilmesi için destek vermeye ve derginin ülkenin her köşesine ulaşması için çalışmaya dair çağrıda bulunur ${ }^{70}$. Ancak, tüm bu çağrılara rağmen, ilk yıllarda dergi neredeyse hiç satılmaz ve bunun üzerine birkaç sayı Milli Kütüphane’ye, diğerleri ise belediyelere ve valiliklere ücretsiz olarak gönderilir ${ }^{71}$.
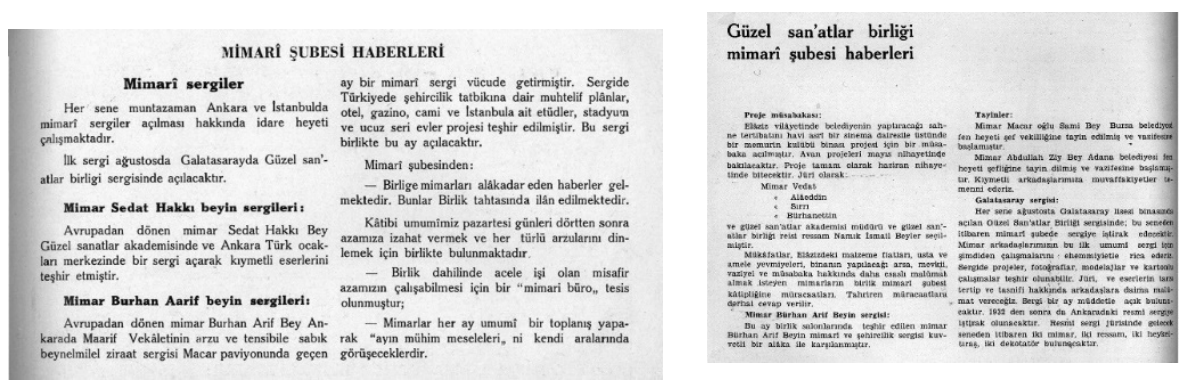

Şekil 4. Güzel Sanatlar Birliği Mimari Şubesi’ne Dair Haberler ${ }^{72}$

Derginin yayın hayatına başladığı yıllarda, ülkede yaklaşık 200 Türk mimarın bulunduğu düşünüldüğünde; Mimar aracılığıyla, bir mesleki iletişim ve etkileşim ortam 1 yaratılması yolundaki çabalar oldukça önemli görünür. Dergi, eğitimli ve diplomalı Türk mimarlarının, erken Cumhuriyet yıllarının kapsamlı imar faaliyetleri bağlamında Avrupa'dan davet edilen yabancı mimarların yoğun mimari etkinlikleri karşısındaki hoşnutsuzluklarını dile getirdikleri ve sorunlarını tartıştıkları bir platform oluşturur ${ }^{73}$. Bu doğrultuda, Mimar,

147.

67 Üstün Alsaç, “Cumhuriyet Döneminde Yayınlanan Mimarlık Dergileri”, Çevre, sayı 1 (1979): 86.

68 Zeki Sayar, "25inci Y1lı Bitirirken”, Arkitekt, say1 4 (1955): 147.

69 Ö. Faruk Galip, "Birlik ve Mecmua”, Mimar, say1 1 (1931): 20.

70 Ö. Faruk Galip, "Birlik ve Mecmua”, 20;; Ö. Faruk Galip, "Mimarlar Kongresi”, Mimar, say1 2 (1931): 67.

71 Zeki Sayar, "Zeki Sayar: Çizdiğini İnşa Etmeyen Bir Mimarı Tasavvur Edemiyorum”, Mimarlık, sayı 4 (1988): 47.

72 Mimar, say1 4 (1931): 143. Mimar, say1 5 (1931): 180

73 Bu yıllarda, yine dergideki yazılardan anlaşıldı ̆̆ı üzere Türk mimarlarının bir birlik oluşturma yolundaki çabaları dikkat çekicidir. Abidin (Mortaş)'ın yazısında vurguladığı üzere, Türk mimarları, "teşkilatsızlık ve programsızlık yüzünden memleketin umumi medeniyet mesaisinde" etkin rol alamamaktadırlar. Bkz. Abidin, "Memleketimizde Mimari Varlık", Mimar, say1 3 (1931): 73. 
biri "senelerce bu mesleği okumuş tetkik etmiş, inceliklerini, yaşayışını, zevklerini, elemlerimi yakından hissetmiş" 74 olan Türk mimarlarının ülkede seslerini duyuracakları, meslekle ilgili sorunları, olayları ve tartışmaları dile getirecekleri bir ortam sağlamak; diğeri ise, dönemin Avrupalı ve Türk mimarlarının çalışmalarını yaygınlaştırmak ve daha geniş kitlelere duyurmak ${ }^{75}$ olmak üzere, iki temel misyon edinmiştir. Zaten Sayar da, bir dergi yayınlamaya karar vermelerinde, mezun olduktan sonra iş bulmak ve mimarlık ortamında kendilerini tanıtmak konusunda yaşadıkları zorlukların etkili olduğunu belirtmektedir ${ }^{76}$.

Derginin bu misyonu edinmesinde, mimarlık alanına ilişkin mesleki konuları incelemek ve gelişmeleri takip etmek gibi meslek alanına özgü çalışmaların yürütülmesi için bir mimarlık dergisi yayınlanmasına duyulan ihtiyaç etkili olmuştur. 1930'larda Türkiye'de henüz kurumsallaşmış bir meslek odası ve dergisi olmadığı için de, "mimarların durumunu belgelemek ve mimarları temsilen kamuoyuna bir mesaj vermek" amacıyla bu görevi, Mimar üstlenmiştir ${ }^{77}$. Dolayısıyla da, Türkiye'de yüzyıllardır sürdürülen oldukça zengin bir yapı geleneği ve mimari etkinlik alanı bulunmasına rağmen, mesleğin statüsünün tam olarak belirlenmemiş olmasından kaynaklanan sorunlar, dergide ele alınan başlıca konular arasında yer bulur. Bu açıdan, dergide yer verilen Şevki Balmumcu'nun sözleri önemli görünür: "Bu memlekette mimar: Halkın kavlince (Mühendis), bir takım vatandaşlar indinde (Kalfa), Mühendislere sorulursa (Ressam), ve san'atkârlar, meselâ ressamlar veya tiyatrocular mabeyninde de Mühendistir."78.

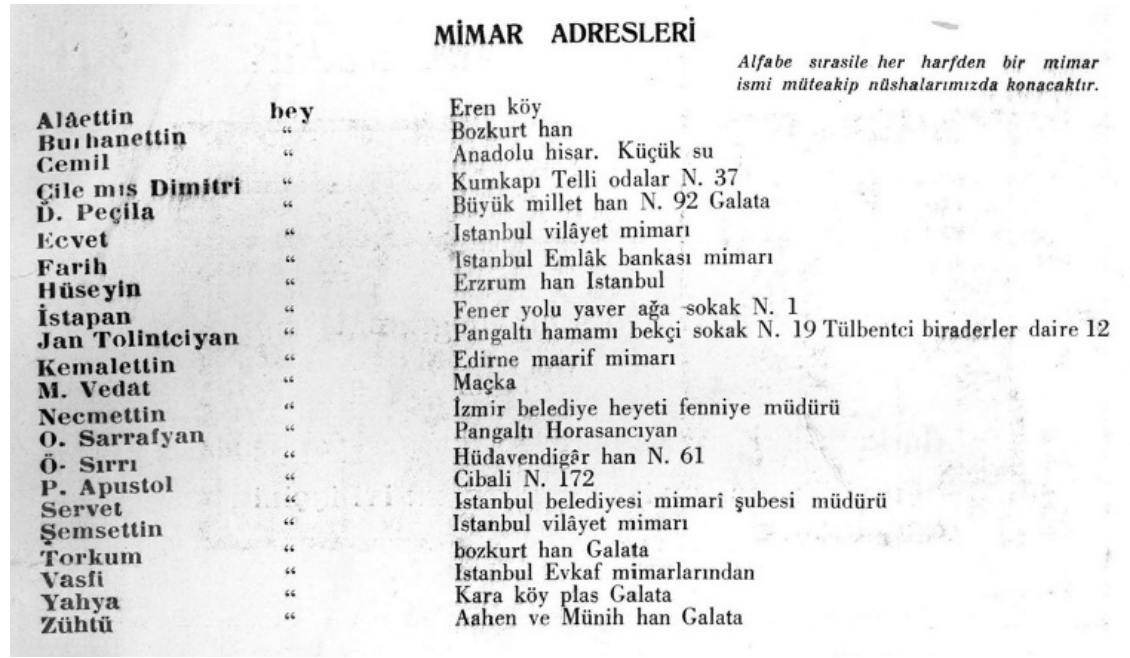

Şekil 5. Mimar Adresleri ${ }^{79}$

74 Galip, "Birlik ve Mecmua”, 20.

75 Baydar, Osmanlı-Türk Mimarlarında Meslekleşme, 77.

76 Sayar, “Zeki Sayar: Çizdiğini İnşa Etmeyen Bir Mimarı Tasavvur Edemiyorum”, 47.

77 Haldun Ertekin, vd., "Söyleşi: Türkiye'de Mimari Yayıncılık”, Mimarlık, sayı 2 (1984): 36.; Sorgucu, vd., "Yayıncılar Tartışıyor". Mimarlık, sayı 250 (1992): 25.

78 Mimar Şevki (Balmumcu), “III”, Mimar, sayı 11-12 (1931): 378.

79 Mimar, sayı 1 (1931): 27. 
Dergi, dönemin yabancı mimarlarının yoğun mimari faaliyetleri karşısında geri planda kalan Türk mimarlarının en büyük destekçisi olmuş ${ }^{80}$ ve dönemin genç Türk mimarlarının çalışmalarına önemli yer ayırmıştır. Bu doğrultuda, dergide, Sedad Hakkı Eldem, Arif Hikmet Holtay, Şevki Balmumcu, Abidin Mortaş, Behçet Ünsal, Burhan Arif, Abdullah Ziya Kozanoğlu ve Celal Esad Arseven gibi dönemin önemli isimlerinin yazılarına sıklıkla yer verilir. Mimari proje yarışmalarına katılan Türk mimarların tasarım önerileri, uygulamaları ve makalelerinin yanı sıra; dönemin Güzel Sanatlar Akademisi Mimarlık Bölümü öğrencilerinin projeleri de öğrencilerin isimleriyle yayınlanır. Hatta, özellikle ilk sayılarda, Türk mimarlarını mimarlık ortamına tanıtmak amacıyla, mimarların isimleri ile birlikte, faaliyet gösterdikleri özel ofisleri veya kamu kurumlarındaki adreslerine ilişkin bir liste olan "Mimar Adresleri" bölümü bulunur (Şekil 5). Böylelikle, dergi, üstlenmiş olduğu mimarlar arasındaki iletişimi sağlama misyonunu da, somut olarak yerine getirir. Ancak, dergide, henüz çok genç olmaları nedeniyle, Türk mimarlarına yönelik eleştirel bir söylemden özellikle kaçınılır ${ }^{81}$. Bu durum, derginin yeterince mücadeleci bir söylem geliştirmediği yolunda bazı eleştirilere yol açsa da; Sayar, bunu oldukça 1lımlı olan kişiliği ile açıklamaktadır ${ }^{82}$.

1935 yılında, Matbuat Umum Müdürlüğü’nden gelen bir yazıyla Mimar kelimesinin Arapça kökenli olması nedeniyle, derginin adının değiştirilmesi istenir. Finlandiya'dan gelen bir derginin üzerinde yer alan "Arkkitehti” ifadesinden yola çıkılarak, Fince'nin tıpk1 Türkçe gibi Ural-Altay dil ailesi kökenli olmasına referansla derginin adı Arkitekt $t^{83}$ olarak değiştirilir ${ }^{84}$. Adı değişmişse de; dergi, yayın hayatı boyunca, aynı kişinin yönetiminde olmasının da yardımıyla, en başta benimsediği modernist çizgisini devam ettirmiştir. $\mathrm{Bu}$ doğrultuda, özellikle Amerika ve Avrupa başta olmak üzere, Almanya ve Japonya'ya kadar çeşitli ülkelerle iletişime geçilerek, buradaki dergilerin karşıllklı olarak gönderilmesi yolunda anlaşmalar yapılır ve Arkitekt'e her ay 30 kadar yabancı mimarlık süreli yayını gelir $^{85}$. Böylelikle, eş zamanlı olarak diğer ülkelerdeki mimarlık yayıncılığı yakından takip edildiği gibi, bu ülkelerdeki güncel mimari yaklaşımlar ve mimari ürünlere dair örneklerle birlikte, yayınlanan çeşitli makalelerin de Türkçe çevirilerine yer verilir. Hatta, bu amaçla, CIAM kongrelerine delegeler gönderilmiş ve bu toplantılarda alınan kararlar ${ }^{86}$, modern şehircilik ilkeleri ve kentlerin imarı konusunda birçok makale yayınlanmıştır. Arkitekt'in, özellikle Fransa' da yayınlanmakta olan mimarlık dergileri ile olan yakın iletişimi ${ }^{87}$, yaklaşık yüzyıl önce, Osmanlı yayıncılığının kuruluş döneminde, Fransız dergi ve gazetelerinin

80 Afife Batur, vd., "Modern Mimarlık Hareketinin Mimarlık Yayınlarında Ele Alınışı ve Yayınların Uygulamaya Etkisi”, Mimarlık, say1 5-6, (1985): 35.

81 Atilla Yücel, vd., "Söyleşi: Türkiye’de Mimarlık Eleştirisi”, Mimarlık, sayı 1 (1985): 26.

82 Bülent Kumral, “Zeki Sayar'la Söyleşi”, Yapı, sayı 152 (1994): 50.

83 Benzer biçimde, Türk Güzel Sanatlar Birliği Mimari Şubesi’nin 1931 yılındaki kongresine ilişkin yayınlanan haberlerde, mimarlar arasında, "mimar" yerine "arkitekt" ifadesinin kullanılması yolunda büyük bir eğilim olduğu ve bu doğrultuda İdare Heyeti’nin, Dil Encümeni'nin fikrini aldıktan sonra hükümete teklifte bulunacağı belirtilir. Bkz. Galip, "Mimarlar Kongresi”, 68.

84 Kumral, “Zeki Sayar'la Söyleşi”, 45.

85 Kumral, “Zeki Sayar'la Söyleşi”, 48.

86 Batur, vd., "Modern Mimarlık Hareketinin Mimarlık Yayınlarında Ele Alınışı ve Yayınların Uygulamaya Etkisi", 35.

87 Sayar, “Zeki Sayar: Çizdiğini İnşa Etmeyen Bir Mimarı Tasavvur Edemiyorum”, 46. 
örnek alınmasıyla başlayan sürecin, erken Cumhuriyet yıllarında halen devam etmekte olduğunu göstermesi açısından ilginçtir.
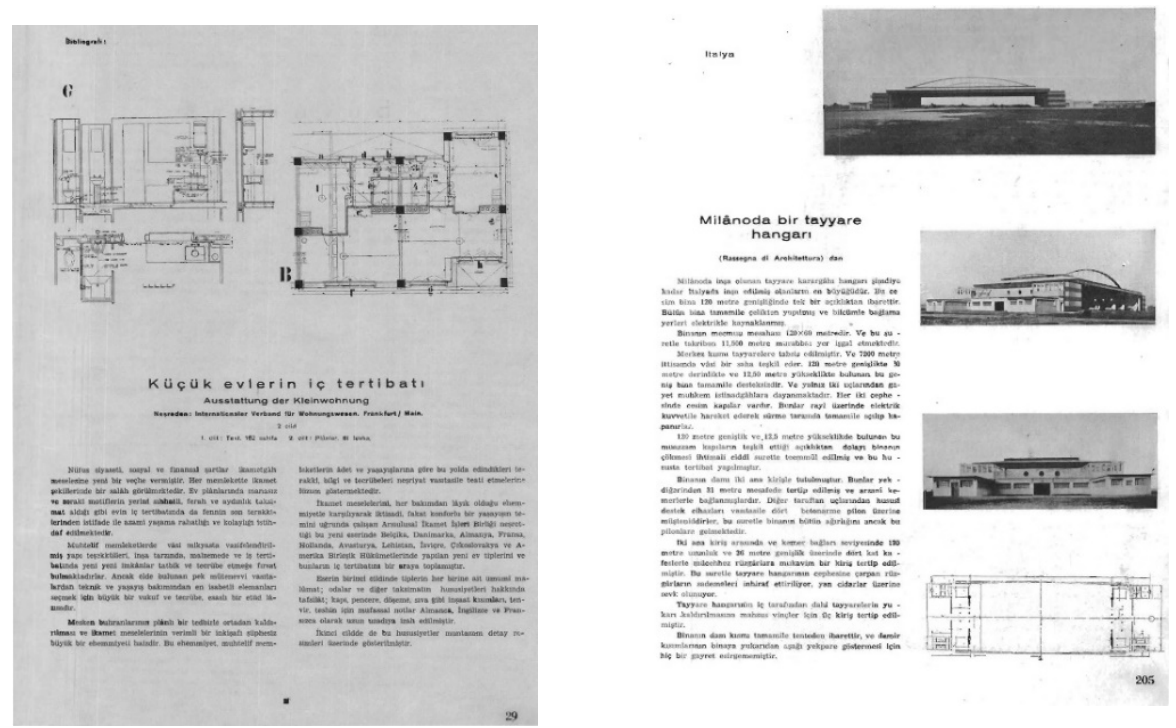

Şekil 6. Diğer ülkelerdeki mimari üretimlere ilişkin yazılar ${ }^{88}$.

Diğer taraftan, dergide, büyük çoğunluğu Akademi'deki eğitim sisteminin modernist eğilimleri benimsediği 1928 yılından önce eğitimlerini tamamlamış olan dönemin mimarlarına modern mimariyi tanitmak amaciyla, stadyum, hal binası, hastane, sinema, laboratuvar, apartman, müze, halkevi, sergi salonları ve tiyatrolar, köprüler, kent meydanı ve heykeller gibi yeni yapı tipolojisine ilişkin tasarım prensipleri ve uygulanmış örnek yapılar, görselleri ile birlikte sunulur (Şekil 6). Bu açıdan, bir yandan böylesi modern mimariyi tanıtıcı içeriğin yanı sıra, bir yandan da Sedad Hakkı Eldem'in uluslararası bir mimari üslup yerine milli mimarinin oluşturulması yolundaki çeşitli yazılarına, söylemlerine ve uygulamalarına yer verilmiş olması, derginin üstlendiği yabancı mimarların etkinlikleri karşısında Türk mimarlarının sesini duyurmak misyonu ile ilişkili görünür. Ayrıca, dergi, yer verdiği betonarme yapım teknikleri, yeni inşaat malzemeleri, yapı malzemelerinin teknik detayları ve fiyat listeleri, yeni inşa teknikleri gibi modern mimarinin uygulanışına dair bilgilendirici reklam ve yazılarla, dönemin genç mimarları için de bir eğitim ortamı oluşturur. Bu bağlamda, derginin, yapı malzemelerine ilişkin reklam sayfaları (Şekil 7), ekonomik kaygının yanı sıra, eğitici ve bilgilendirici içerikleriyle derginin önemli bölümlerinden birini meydana getirmiştir. 

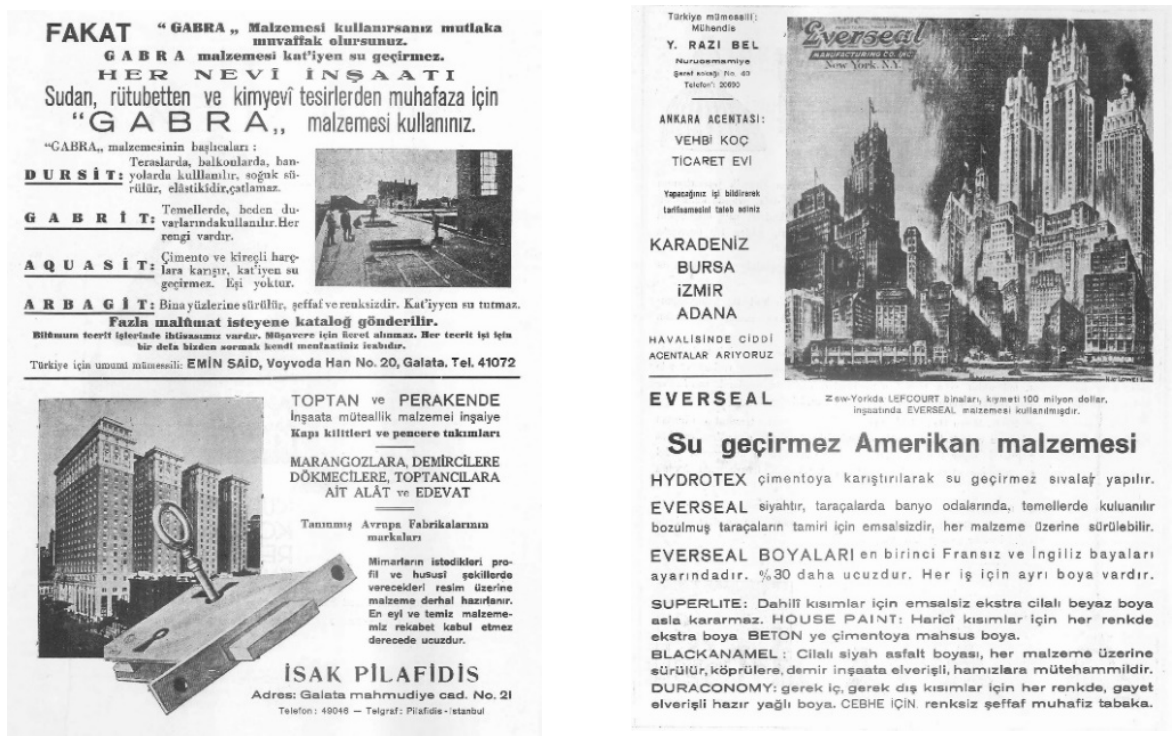

Şekil 7. Yapı Malzemesi Reklamlar1 ${ }^{89}$

Sayar'a göre, bir derginin içeriğinin \%10 veya daha azı yabancı mimarların gerçekleştirdiği çalışmalardan, \%40’1 projelerden ve \%50'si de makalelerden meydana gelmelidir. Bu doğrultuda, birkaç sayı istisna olmak üzere, Arkitekt, 1930'larda büyük ölçüde bu düşünceyle yayınlanmışsa da, sonraki yıllarda, özellikle 1970'lerden sonra makalelerin oranı azalacak ve projelerin oranı ise artacaktır ${ }^{90}$.

Arkitekt'in de benimsediği dönemin modern mimarlık anlayışında, mimar, yalnızca yap1 değil; mobilyadan, duvar kağıdına, halı ve kilimden aydınlatma elemanına kadar her türlü tasarım nesnesinin tasarımsal ve düşünsel üretimini yapan bir sanatçıdır. Bu doğrultuda, Arkitekt’te de yalnızca mimarlık değil, seramik, heykel, resim vb. gibi farklı güzel sanatlar disiplinlerine ilişkin yazılara da yer verilmiştir. Sayar, derginin bu kapsamlı içeriğinin, dönemin tek resmi mimarlık okulu olan Güzel Sanatlar Akademisi'ndeki mimarlık eğitiminin, okuldaki resim, heykel ve seramik gibi diğer güzel sanatlar eğitimleri ile olan yakın ilişkisiyle bağlantılı olduğunu belirtir ${ }^{91}$. Derginin içeriğinin yalnızca mimarlık alanıyla sınırlı olmadığını, aynı zamanda derginin çeşitli yıllarda değişen alt başlıklarından okumak olanaklıdır. Bu bağlamda, 1933 yılında dergi, "Aylık Yapı Sanatı, Şehircilik ve Tezyinî San'atlar Mecmuası” alt başlığını almakla birlikte; 1935 yılında "Aylık Yapı Sanatı, Şehircilik ve Dekoratif San'atlar Dergisi”" alt başlığı, 1941 yılında ise "Aylık Yapı Sanatı, Şehircilik ve Süsleyici San’atlar Dergisi”, 1944 yılında önce "Aylık Yapı Sanatı, Şehircilik ve Dekoratif Sanatlar Dergisi" devamında ise "Aylık Yapı Sanatı, Şehircilik ve Süsleme Sanatları Dergisi” alt başlı̆̆ıyla yayınlanmıştır. 1945 yılında "Aylık Mimarlık, Şehircilik ve Süsleme Sanatları Dergisi” ve 1951 yılında da "Aylık Mimarlık, Şehircilik ve Belediyecilik Dergisi" alt başlığını almıştır.

\footnotetext{
89 Arkitekt, say1 2 (1935).

90 Afife Batur, "A Tribute to Zeki Sayar”, Mimar, sayı 10 (1983): 84.

91 Kumral, “Zeki Sayar'la Söyleşi”, 48.
} 
1940’larda, mimari yazın ortamına yeni mimarlık süreli yayınları da katılır. Ancak 1980'lere kadar, birbirinden farklı mimari anlayışları ve yaklaşımları savunan yaklaşık 15 mimarlık dergisi yayın hayatına başlamışsa da; bunlardan yalnızca birkaçı uzun süreli olabilmiştir. Bu bağlamda, Arkitekt'i, "Mimari, Güzel Sanatlar, Fikir ve Kültür Dergisi" alt başlığıyla, 15 günde bir olmak üzere yayınlanan Yapı dergisi izlemiştir. Tahir Tuğ, Mimarlar Birliği ve Güzel Sanatlar Birliği Mimari Şubesi İdari Heyeti’nde görev alan Sedat Çetintaş, İsmet Barutçu, Necmi Ateş, Fazıl Aysu² ve Behçet Ünsal ile birlikte hem mimar profesyonellerin hem de toplumun her kesiminden bireyin okuyabileceği güncel mimari bilgileri içeren Yapı dergisini, "meslekte tekelleşmeyi önlemek için mücadele verebilmek" amacıyla yayınladıklarını belirtir. 1941'den 1943 sonlarına kadar iki yıl boyunca yayın hayatına devam eden dergiye, aynı zamanda Milli Ĕ̆itim, Halkevleri, Bayındırlık ve diğer resmi kurumlar da abone olmuşlardır. Amatör bir ekip tarafından hazırlanmakla birlikte, Tuğ'a göre, bir "mimari yayının yalnız meslektaşlara değil, aynı zamanda entelektüel vatandaşlara da hitap etmesi” gereklidir" ${ }^{93}$. Gerek bu düşünceyle, gerek derginin II. Dünya Savaşı'nın yol açtığı zorlu ekonomik koşullar altında çıkarılıyor olması, gerekse de dergiyi çıkaranların benimsemiş olduğu Bauhaus temelli mimarlık düşünceleri ile bağlantılı olarak, dergide, mimarlık "bütün sanatların ana kucağı” olarak ele alınmıştır. Bu doğrultuda da, mimarlığın yanı sıra, resim, fotoğraf, şiir, tiyatro gibi diğer güzel sanatlar alanlarına ilişkin yazılara da yer verilmiştir ${ }^{94}$.

Yapı dergisinin yayın hayatını sonlandırmasıyla, mimarlık yazını yeni bir mimarlık süreli yayını ile tanışır: "Yapı Sanatı, Şehircilik ve Güzel Sanatlar Dergisi” alt başlığıyla, 1944 ile 1953 yılları arasında yayınlanan Mimarlık. İki ayda bir yayınlanan derginin içeriğinde, Türk Yüksek Mimarlar Birliği tarafından yayınlanması ile ilişkili olarak, ağırlıklı biçimde birliğin çalışmalarına yer verilir. Ayrıca, mimarlık ve şehircilik yarışmaları, seçici kurul raporları, çeviriler, kitap tanıtımları da dergide yer alan diğger konular arasındadır ${ }^{95}$. Mimarlık, aynı zamanda, Ankara' da yayınlanan ilk mimarlık süreli yayını olmakla birlikte; Tanyeli'ye göre, "yayıncıları neredeyse Arkitekt' in Ankara versiyonunu yapmayı amaçlamışlardır"96. Derginin mimarlık ortamına en önemli katkılarından biri, 1948 yılında Birinci Türk Yap1 Kongresi'nin hazırlanması ve toplanması yolundaki destekleyici yazıları olmakla birlikte; Mimarlık dergisini, daha önce yayınlanan diğer süreli mimarlık yayınlarından ayıran en temel özelliği, ulusal mimarlık düşüncesini savunmasıdır ${ }^{97}$. Aslında bu durum, II. Dünya Savaşı'nın etkilerinin yoğun biçimde hissedildiği mimarlık ortamının da bir yansımasıdır. Derginin yayınlandığı yıllar, tam da, Türkiye’de II. Ulusal Mimarlık akımının biçimlendiği ve bu doğrultuda çeşitli mimari üretimlerin gerçekleştirildiği yıllara denk gelmektedir.

92 Alsaç, Yapı dergisinden bahsederken, kurucuları arasında Fazıl Aysu yerine, Turgut Tokad'ın ismini vermektedir. Bkz. Alsaç, "Cumhuriyet Döneminde Yayınlanan Mimarlık Dergileri”, 87.

93 Ertekin, vd., "Söyleşi: Türkiye'de Mimari Yayıncılık”, 37.

94 Alsaç, "Cumhuriyet Döneminde Yayınlanan Mimarlık Dergileri", 87.

95 Alsaç, "Cumhuriyet Döneminde Yayınlanan Mimarlık Dergileri”, 87.

96 Tanyeli, "Mimarlık’ın 300. Sayısı ve Sektörün Tarihi Bağlamında Bugün Türkiye'de Mimarlık Dergiciliăii", 36.

97 Alsaç, "Cumhuriyet Döneminde Yayınlanan Mimarlık Dergileri”, 87. 
Erken dönemdeki, bir diğer süreli yayın ise, 1947 yılında "Mimarlık, Resim, Heykel, Dekorasyon, Musiki, Tiyatro ve Sinema Dergisi" alt başlığıyla, Selçuk Milar tarafından yayınlanan Eser'dir. Ankara'da aylık olarak yayınlan dergi, yayın hayatını ancak iki sayıyla, bir yıl boyunca devam ettirebilmiştir ${ }^{98}$. Derginin içeriğinde, Bedri Rahmi Eyüboğlu, Adnan Saygun ve Abidin Dino gibi dönemin önemli sanatçılarının yazılarına ve resimlerine yer verilmekle birlikte, şiir ve karikatürle ilgili yazılar da yayınlanmışıtır. Bu yayında da, diğerleri gibi, mimarlığı, diğer sanat dallarından ayrıştırmayan bir yaklaşım söz konusudur ${ }^{99}$. Ancak, bu dergilerin kısa ömürlü olmalarının başlıca nedeni, Sayar'a göre, amatörce yayınlanıyor olmaları ile ilişkilidir ${ }^{100}$.

1953 yılında Mimarlık'ın yayın hayatını sonlandırmasıyla birlikte, 1960'ların başlarına kadar, Arkitekt, yine ülkedeki tek mimarlık süreli yayını olarak varlığını sürdürür. 1961 ile 1964 yılları arasında Bülent Özer tarafindan yayınlanan Mimarlık ve Sanat, 1963 'te TMMOB Mimarlar Odası yayını olan Mimarlık, 1973'te Doğan Hasol tarafından yayınlanan Yapı ve 1979 yılında Selçuk Batur tarafından yayınlanan Çevre başta olmak üzere çeşitli mimarlık dergileri yayınlanmaya başlamışsa $\mathrm{da}^{101}$; bu dergilerin birkaçı dışındakiler ne yazık ki, uzun süreli olamamışlardır.

\section{Sonuç}

İlk örnekleri, 17. yüzyıl sonlarında Aydınlanma düşüncesinin yol açtığı ifade ve düşünce ortamında ortaya çıkan süreli yayınlar, endüstrileşmenin sağladığı teknolojik olanaklarla birlikte, 19. yüzyıldan itibaren toplumsal hayatın etkileşim ve gelişimini sağlayan en önemli araçlar haline gelmiştir. Bu süreç, bir yandan da, endüstrileşmenin mimarlığın her alanında radikal değişikliklere yol açmasıyla bağlantılı olarak, modern bir meslek adamı olarak mimarın (professional architect) doğuşuna işaret etmektedir ${ }^{102}$. Artık mimar, kendine ait bireysel mesleki düşünceleri olan ve bu doğrultuda üretimler yapan, yalnızca mimari pratik değil aynı zamanda mimari söylem de ortaya koyan bir düşünce insanıdır. Aynı zamanda, mimar, artık, yapı üretim etkinliğindeki tek aktör değildir. Yapı üretim etkinliği, mimarın yanı sıra, mühendisler ve müteahhitler başta olmak üzere, giderek karmaşıklaşan ilişkilerin tanımladığ farklı mesleklerden bireylerin ortaklaşa gerçekleştirdikleri bir üretim haline gelmiştir. Dolayısıyla, bu aktörler de, geleneksel üretimdeki gibi mesleğe ilişkin fikirlerini diğerlerine aktarmak için bireysel iletişim araçlarının ve karşılıklı sözlü diyaloğun yetersiz kaldığı bu yeni ortamda; düşüncelerini tüm topluma iletebilecekleri yeni bir iletişim biçimine ihtiyaç duymaktadırlar.

Bu bağlamda, yeni bir iletişim dili tanımlayan mimarlık süreli yayınları da, toplumsal ve mekânsal problemlerin kaotik ortamında, birbirinden farklılaşan mimari söylemlerin, üretim biçimlerinin ve yaklaşımların birbirine üstün gelme ve meşruiyet kazanma yolunda varlık kazanmışlardır. Yüzyıl boyunca da, mimari üsluplar, akımlar, düşünceler ve teorileri

\footnotetext{
98 Ertekin, vd., "Söyleşi: Türkiye'de Mimari Yayıncıllk", 35.

99 Alsaç, "Cumhuriyet Döneminde Yayınlanan Mimarlık Dergileri”, 87.

100 Ertekin, vd., "Söyleşi: Türkiye'de Mimari Yayıncılık”, 36.

101 Ertekin, vd., "Söyleşi: Türkiye'de Mimari Yayıncılık", 35.

102 Wilton-Ely, "The Rise of the Professional Architect in England", 190.
} 
yaymak ve yaygınlaştırmak adına temel bir kaynak, bir iletişim aracı olmuşlardır. Üstelik, bu yeni mimari iletişim aracı, yazın alanındaki bir diğer araç olan kitaba göre, sıklıkla ve çok sayıda basıldığı, dolayısıyla da daha geniş bir okuyucu kitlesine ulaşabildiği için, düşüncelerin daha hızlı yayılmasını sağlamakta ve daha çok kişiye ulaşan bir mecra tanımlamaktadır.

Bu nokta da, ilk mimari süreli yayınlarının, yapı üretim etkinliğinin gerçekleştirilme biçiminin ilk olarak değişmeye başladığ 1 ve endüstrileşmenin mimarlık ortamında yol açtığ 1 sorunlarla ilk karşılaşan İngiltere, Fransa ve Almanya gibi erken endüstrileşen ülkelerde ortaya çıkması hiç de şaşırtıcı değildir. Keza, endüstrileşmenin belirlediği yapı üretiminin artık en önemli aktörlerinden biri olarak beliren müteahhitler tarafından yayınlanan bu ilk süreli yayınlar, büyük ölçüde, yapı ve inşaat malzemelerinin tanıtımını sağlayan reklamlar, yapı katalogları, malzeme fiyatlarına ilişkin listeler vb. gibi içeriklere sahip olan ticari nitelikli dergilerdir.

Türkiye'deki ilk mimarlık süreli yayını da, mimarlık alanındaki manifester söylemlerin yanı sıra, modern hareketin de neredeyse tüm dünyaya yayılarak uluslararası bir üslup haline geldiği böylesi bir ortamda, 20. yüzyılın ilk yarısında varlık kazanmıştır. Ancak, henüz manifester bir söylem üretecek ne bir mimarlık ortamı ne de mimar topluluğu söz konusudur. Dolayısıyla, erken Cumhuriyet yıllarında ortaya çıkan ilk Türk mimarlık süreli yayını Mimar/Arkitekt, mesleki-ticari bir dergi olarak ortaya çıkmıştır ${ }^{103}$. Böylesi bir yayının ortaya konması, Türkiye'deki mimarlık kültürü için önemli bir adım olduğu kadar, mimar kimliği için de önemli bir eşik tanımlamaktadır. Arkitekt, erken Cumhuriyet mimarlarının, ilk kez mimar kimliklerini, mühendislerden ayrışmış bir meslek topluluğu olarak inşa etme yolundaki ortak çabalarının bir ürünüdür ${ }^{104}$. Bu bağlamda, erken Cumhuriyet yılları, mimarlık ortamı için, -tıpkı 19. yüzyılın erken endüstrileşen ülkelerinde olduğu gibi- aynı zamanda da bir profesyonelleşme sürecidir. Bu profesyonelleşmenin ihtiyaç duyduğu araçlardan biri de, mimarlık süreli yayınlarıdır.

Ancak, Mimar/Arkitekt, Batılı öncüllerinden farklı olarak, müteahhitler değil, mesleki olarak kendilerini tanımlamayı ve tanıtmayı amaçlayan bir mimar grup tarafından yayınlanmıştır. Dolayısıyla, her ne kadar içeriğinde, tıpkı öncülleri ve eşzamanlı eşdeğerleri gibi görsellere, makalelere, yapı malzeme reklamlarına ve fiyatlarına yer verilmişse de; öncelikli hedef, mimarların birbirleri ile iletişim kuracakları bir platform oluşturmaktadır. Bu yıllarda, ülkede tek mimarlık okulu olması nedeniyle, aslında az sayıda Türk mimar vardır. Bu mimarlar da, erken Cumhuriyet yıllarının modernleşme projesi çerçevesinde yürütülen imar faaliyetleri ile bağlantılı olarak, ülkenin dört bir yanına dağılmış durumdadır. Dolayısıyla, dergi, bir yandan az sayıdaki Türk mimarın az sayıdaki mesleki üretimlerinden herkesi haberdar etme, bir yandan da kurucularının da benimsediği modern hareket doğrultusunda, örnek alınan Batı dünyasındaki mimari modernlikleri, her yönüyle detaylı biçimde Türk mimarlarına tanıtma amacındadır.

103 Tanyeli, "Mimarlık’ın 300. Sayısı ve Sektörün Tarihi Bağlamında Bugün Türkiye'de Mimarlık Dergiciliği”, 35.

104 Baydar, Osmanlı-Türk Mimarlarında Meslekleşme, 58. 
Sayar'a göre, Mimar/Arkitekt, "yeni bir mimarlık kuşağının yetiştiği” bu yıllarda, ülkedeki mesleki yayın eksikliğini gidermeye çalışmaktadır ${ }^{105}$. Ancak, bu durum aynı zamanda, derginin içeriğinde, tıpkı öncülleri gibi mimarlı̆̆a dair her şeye yer verilmesini beraberinde getirmiştir. Şehircilikten yapı malzemesi reklamlarına, inşaat tekniklerinden mimari yarışma projelerine, öğrenci projelerinden malzeme fiyatlarına, mimarların adreslerinden sanat üretimlerine kadar, neredeyse her biri biraraya gelmez görünen pek çok konu, bir arada sunulmuştur. Diğer taraftan, içeriğin bu denli geniş bir yelpazede olması, zaten yeniden inşa sürecinde olan ülkenin, kısıtlı ekonomik ve toplumsal koşullarında, okurların tek bir dergi aracılığıyla, her şeyi bir arada bulmalarına da olanak sağlamıştır.

Bu yönüyle de, henüz mimari eleştiri ve söylemin inşa edilmediği bu yıllarda, sayıca az bir okuyucu kitlesi olsa da, Mimar/Arkitekt, Türkiye'deki mimarlık kültürünün en önemli temel taşlarından birini tanımlamıştır. Özellikle, erken Cumhuriyet yıllarının mimarlık ortamında, genç Türk mimarları için aynı zamanda eğitici ve öğretici bir rol üstlenmiştir. Sayar'ın kişisel çabaları ile 1980'lere kadar, yaklaşı 50 yıl boyunca -kimi zaman ayda bir, kimi zaman iki ayda bir yayınlansa da- yayın hayatını kesintisiz sürdürmüş ve en uzun soluklu Türk mimarlık süreli yayını olmuştur.

\section{Kaynakça}

Abidin. "Memleketimizde Mimari Varlık". Mimar, say1 3 (1931): 73-74.

Alsaç, Üstün. "Cumhuriyet Döneminde Yayınlanan Mimarlık Dergileri”. Çevre, sayı 1 (1979): 86-90.

Batur, Afife. "A Tribute to Zeki Sayar". Mimar, say1 10 (1983): 76-85.

Batur, Afife; Batur, Selçuk; Bilgin, İhsan; Gerçek, Cemil. "Modern Mimarlık Hareketinin Mimarlık Yayınlarında Ele Alınışı ve Yayınların Uygulamaya Etkisi”. Mimarlık, say1 5-6 (1985): 35-38.

Baydar, Gülsüm. Osmanlı-Türk Mimarlarında Meslekleşme. Ankara: TMMOB Mimarlar Odas1 Yayınları, 2012.

Bozdoğan, Sibel. Modernizm ve Ulusun İnşası Erken Cumhuriyet Türkiyesi'nde Mimari Kültür. İstanbul: Metis Yayınları, 2012.

Cezar, Mustafa. Devlet Güzel Sanatlar Akademisi'nin 90. Yılı. İstanbul: Devlet Güzel Sanatlar Akademisi, 1973.

Demir, Kenan. "Osmanlı'da Dergiciliğin Doğuşu ve Gelişimi (1849-1923)”. Iğdır Üniversitesi Sosyal Bilimler Dergisi, say1 9 (2016): 71-112. 
Ertekin, Haldun; Sayar, Zeki; Tuğ, Tahir; Özer, Bülent; Hasol, Doğan; Sözen, Metin; Aksoy, Erdem. "Söyleşi: Türkiye'de Mimari Yayıncılık". Mimarlık, sayı 2 (1984): 34-43.

Galip, Ö. Faruk. "Birlik ve Mecmua". Mimar, say1 1 (1931): 20.

Galip, Ö. Faruk. "Mimarlar Kongresi”. Mimar, say1 2 (1931): 67-68.

Günergun, Feza. "Son Osmanlı Döneminde Mimar ve Mühendis Meslek Örgütleri ve Dergileri”. Mimarlık, sayı 300 (2001): 26-28.

Günergun, Feza. "Osmanlı Mühendis ve Mimarları Arasında İlk Cemiyetleşme Teşebbüsleri”., Ek-5. Cumhuriyet Mimarlı̆̆ının Kuruluşu ve Kurumsallaşma Sürecinde Türk Mimarlar Cemiyeti'nden Mimarlar Derneği 1927'ye, 249-270. Ankara: Mimarlar Derneği 1927, 2002.

Günergun, Feza. "Osmanlı Mühendis ve Mimarları Arasında İlk Cemiyetleşme Teşebbüsleri”. Osmanlı Mühendis ve Mimar Cemiyeti Belgeleriyle, 41-73. Ankara: TMMOB Mimarlar Odası Ankara Şubesi, 2008.

Hultzsch, Anne \& Moreno, Catalina Mejia. "Introduction: Building Word Image, a New Arena for Architectural History". Architectural Histories, 4(1): 13 (2016): 1-6.

Kumral, Bülent. “Zeki Sayar'la Söyleşi’. Yapı, sayı 152 (1994): 44-52.

Lipstadt, Helene. "Early Architectural Periodicals". The Beaux-Arts and Nineteenth-Century French Architecture, ed. Robin Middleton 50-57. Thames and Hudson, 1984.

Mimar Şevki (Balmumcu). "III". Mimar, sayı 11-12 (1931): 378.

Okay, Cüneyt. "Osmanlı Mühendis ve Mimar Cemiyeti ve Belgeler". Osmanlı Mühendis ve Mimar Cemiyeti Belgeleriyle, 75-176. Ankara: TMMOB Mimarlar Odası Ankara Şubesi, 2008.

Parnell, Steve. "Architectural Design, 1954-1972: The Architectural Magazine's Contribution to the Writing of Architectural History", PhD Thesis, University of Sheffield School of Architecture, 2011.

Özgüven, Yekta. “Türkiye’de Kadın Mimar Kariyerinin Başlangıcı (1934-1960)”, Yüksek Lisans Tezi, Yıldız Teknik Üniversitesi Fen Bilimleri Enstitüsü, 2002.

Sayar, Zeki. "25inci Yılı Bitirirken". Arkitekt, say1 4 (1955): 147, 163.

Sayar, Zeki. "Zeki Sayar: Çizdiğini İnşa Etmeyen Bir Mimarı Tasavvur Edemiyorum”. Mimarlık, say1 4 (1988): 45-47.

Sorgucu, Erdal; Tanyeli, Uğur; Akay, Zafer; Yurdakul, Recep; Sağdıç, Barbaros; Tibet, Raşit; Kartal, Mehmet; Seğmen, Ülker; Özbay, Hasan; Tümertekin, Zehra; Balamir, Murat; Așcıkoca, Haldun. "Yayıncılar Tartışıyor". Mimarlık, sayı 250 (1992): 23-36.

Tanyeli, Uğur. "Mimarlık Dergisi Neyi Temsil Eder? 20. Yüzyıla Bir Bakış". Arredamento Mimarlık, say1 2000/12 (2000): 97-102.

Tanyeli, Uğur. "Mimarlık'ın 300. Sayısı ve Sektörün Tarihi Bağlamında Bugün Türkiye'de Mimarlık Dergiciliği”. Mimarlık, sayı 300 (2001): 34-36.

Ünalın, Çetin. Cumhuriyet Mimarlığının Kuruluşu ve Kurumsallaşma Sürecinde Türk Mimarlar Cemiyeti'nden Mimarlar Derneği 1927'ye. Ankara: Mimarlar Derneği 1927, 2002.

Ünalın, Çetin. "Türk Mühendis ve Mimar Odaları Birliği Kanununun Yasalaşması”. Mimar. ist, say1 51 (2014): 58-66. 
Wilkinson, Catherine. "The New Professionaslism in the Renaissance". The Architect: Chapters in the History of the Profession, ed. S. Kostof, 124-160. New York: Oxford University Press, New York, 1977.

Wilton-Ely, John. "The Rise of the Professional Architect in England". The Architect: Chapters in the History of the Profession, ed. S. Kostof, 180-208. New York: Oxford University Press, 1977.

Yücel, Atilla; Balcıŏglu, Emin Mahir; Batur, Afife; Özer, Bülent; Sayar, Zeki. "Söyleşi: Türkiye'de Mimarlık Eleştirisi”. Mimarlık, sayı 1 (1985): 26-30.

Yeğül, Fikret K. "Vitruvius ve De Architectura". Mimarlık Üzerine On Kitap, ix-xviii. Şevki Vanlı Mimarlık Vakfı Yayınları, 2005.

Arkitekt. say1 1, (1935).

Mimar. say1 1, (1934).

The Architectural Magazine. (Mart 1834).

The Builder's Magazine. (1774).

"Mimar Adresleri". Mimar, sayı 1 (1931): 27.

"Mimarî Şubesi Haberleri”. Mimar, sayı 4 (1931): 143.

“Güzel San’atlar Birliği Mimarî Şubesi Haberleri”. Mimar, say1 5 (1931): 180.

"Reklamlar". Arkitekt, say1 2 (1935).

“Küçük Evlerin İç Tertibatı". Arkitekt, sayı 1 (1937): 29.

“Milânoda Bir Tayyare Hangarı”. Arkitekt, say1 7 (1938): 205-206. 